\title{
Seismic Hazards and Land-Use Planning
}

GEOLOGICAL SURVEY CIRCULAR 690
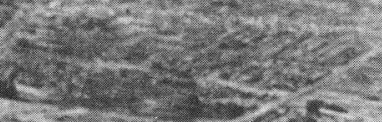

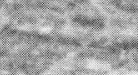

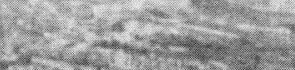

(2)

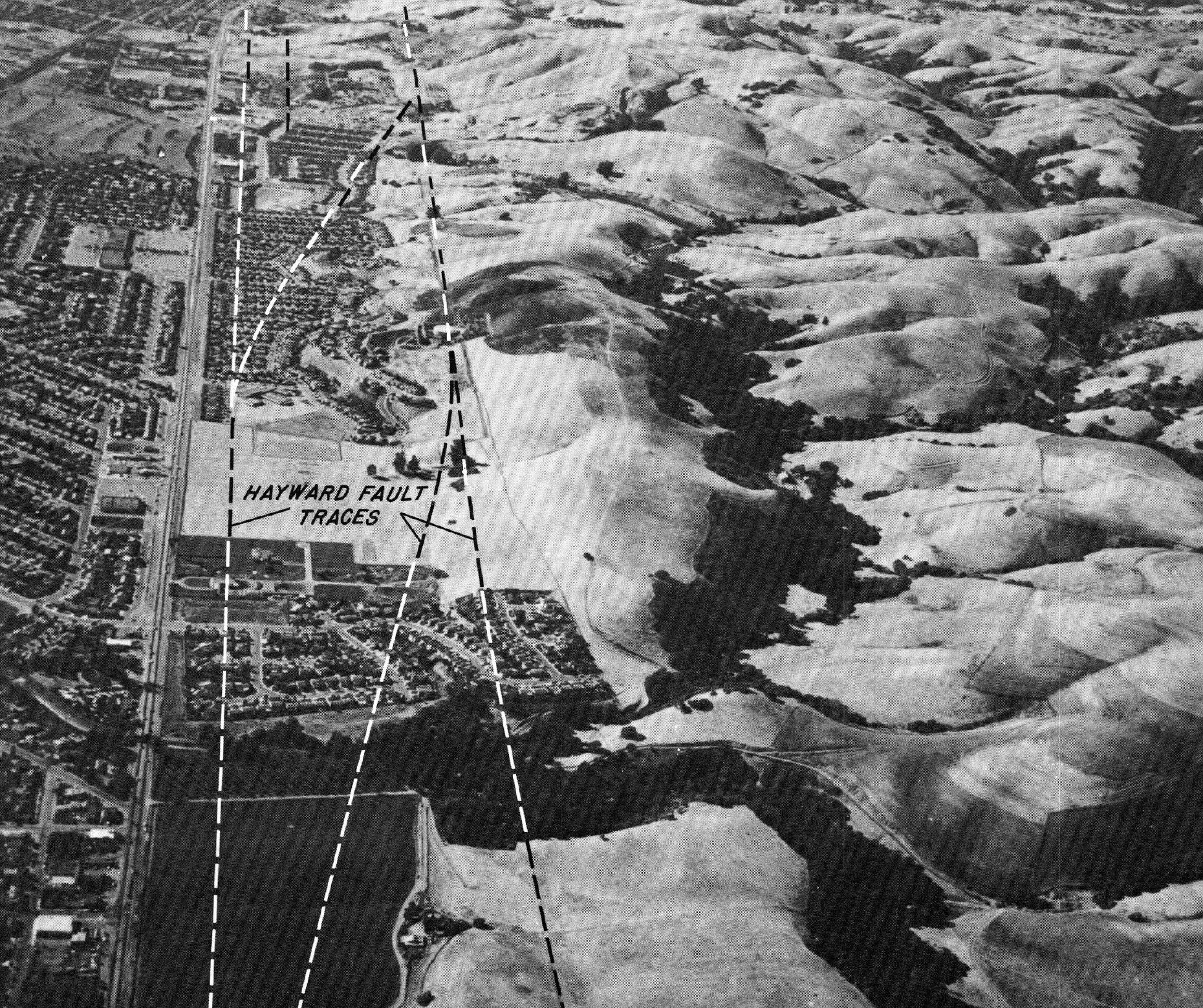





\section{Seismic Hazards and Land-Use Planning}

By D. R. Nichols and J. M. Buchanan-Banks

GEOLOGICAL SURVEY CIRCULAR 690 


\section{U.S. DEPARTMENT OF THE INTERIOR MANUEL LUJAN, Jr., Secretary}

\section{U.S. GEOLOGICAL SURVEY \\ Dallas L. Peck, Director}

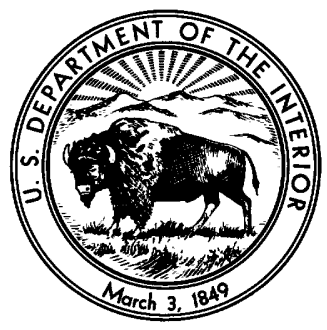

First printing 1974

Second printing 1974

Third printing 1975

Fourth printing 1980

Fifth printing 1990 


\section{CONTENTS}

Abstract

Introduction

Acknowledgments

Seismic hazards and implications for land use

Surface faulting

Methods for assessing fault hazards ..........

Implications for planning and land-use controls

Ground shaking

Methods for assessing shaking hazards

Implications for planning and land use

Ground failure

Mechanisms of failure

Results of ground failure
Page

1

Seismic hazards and implications for land use-Con.

Ground failure-Continued

Methods for assessing ground failure hazards_- 20

Implications for planning and land-use controls 20

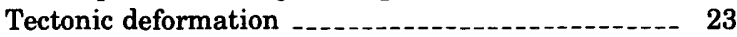

Tsunami and seiche effects _..._-_._-_._-_._-_.-. 24

Methods for assessing wave and flooding hazards 26

Implications for planning and land-use controls 26

Earth-science data needed to assess seismic hazards $\quad$-- $\quad 28$

Principal sources of geologic and seismic data _...... 29

Glossary

References cited

\section{0}

32

\section{ILLUSTRATIONS}

FIGURE 1. Photograph of house damaged by reverse faulting, San Fernando earthquake

2. Map of recently active breaks along the San Andreas fault near Point Arena, Calif

3. Sketch of progressive lateral displacement along a single trace of the San Andreas fault

4. Map showing relation of branch and secondary faults to the main fault trace

5. Graph of relationship of amount of displacement to length of surface rupture on the main fault trace

6. Block diagrams of examples of some types of fault displacement and earth flexure

7. Photograph of curb displaced by fault creep on the Hayward fault

8. Photograph of corral fence deformed and displaced 21 inches by creep along the San Andreas fault

9. Map showing the location of USGS seismograph stations in central California -

10. Sketch showing example of minimum building setback easements along active fault traces in Portola Valley, Calif

11. Oblique aerial view of the approximate location of fault traces within a part of the Hayward fault zone

12. Map showing schools, hospitals, and other public buildings on or near the traces of part of the Hayward fault

13. Aerial photograph of San Francisco showing relationship of greatest damage in the 1906 earthquake to areas of former bay and marshlands

14. Graph relating structural damage intensity for different height buildings to depth of soil -.-.-.--

15. Seismograph records showing the differences in amplification of energy with increased thickness of bay mud

16-24. Photographs of:

16. Unreinforced parapets which collapsed and caused severe damage during moderate Santa Rosa earthquake

17. Sand, liquefied during the 1973 Point Mugu earthquake, which fails to support the weight of a man

18. The Juvenile Hall landslide generated by the 1971 San Fernando earthquake

19. Tilting and sinking of buildings, caused by liquefaction, during the 1964 Niigata, Japan, earthquake and residents salvaging belongings by carrying them down the exterior walls of apartment building

20. Lateral spreading of soft, surficial materials during the 1973 Point Mugu earthquake

21. Ground cracks in flood-plain sediments from 1964 Alaskan earthquake

22. Ground lurching in tidal muds of Tomales Bay, Calif. from 1906 earthquake

23. Sand volcanoes formed during the 1973 Point Mugu earthquake

24. Sand ridges formed by the 1964 Alaskan earthquake

25. Map showing landslide distribution in Mount Diablo area, California

26. Photograph of regional flooding of the Portage, Alaska, area due to tectonic land changes

27. Photograph of tsunami damage from 1964 Alaskan earthquake

28. Sketch map of Vaiont Reservoir, Italy, and flooded area from landslide-induced waves

29. Photograph of destruction area from a giant wave caused by a rockslide in Lituya Bay, Alaska 
TABLE

Page

TABLE 1. Some economic costs resulting from development on unstable areas 


\title{
Seismic Hazards and Land-Use Planning
}

\author{
By D. R. Nichols and J. M. Buchanan-Banks
}

\section{ABSTRACT}

Basic earth-science data are necessary for a realistic assessment of seismic hazards and as a basis for limiting corrective land-use controls only to those areas of greatest hazard. For example, the location, character, and amount of likely displacement and activity of surface faulting can be predicted if detailed geologic maps and seismic data are available and are augmented by field studies at critical localities. Because few structures can withstand displacement of their foundations, they should be located off active fault traces, the distance varying with the character of faulting, the certainty with which fault traces are known, and the importance of the structure. Recreational activities and other nonoccupancy land uses should be considered for fault zone areas where land is under pressure for development; elsewhere, such areas should remain as open space.

Two methods of predicting ground shaking effects have applications to land-use decisions: (1) Relative earthquake effects can be related to firmness of the ground and can be used in a gross way to allocate population density in the absence of more sophisticated analyses; and (2) intensity maps, based on, (a) damage from former earthquakes, or (b) a qualitative analyses of geologic units added to a design earthquake, can be helpful both for general and specific plans. Theoretical models are used with caution to predict ground motion for critical structures to be located at specific sites with unique foundation conditions. Fully adequate methods of assessing possible shaking remain to be developed. Where land-use decisions do not reflect likely ground shaking effects, stringent building codes are needed, particularly for important structures.

Ground failure (landsliding, ground cracking and lurching, differential settlement, sand boils, and subsidence) commonly results from liquefaction, loss of soil strength, or compaction. Areas suspected of being most likely to fail should not be developed unless detailed site studies can demonstrate the hazard does not exist or can be overcome. Various methods can be used to reduce the high, long-term public costs that follow development of unstable ground. However, areas subject to tectonic deformation generally cannot be predicted nor can effects of such deformation be minimized.

Large water waves, such as produced by tsunamis, seiches, and dam failure or overtopping, can be anticipated in many places. Their effects can be lessened by land-use regulations similar to flood-plain zoning, restrictions on location of critical structures, and appropriate warning systems.

Many local, state, and federal government agencies, univer- sities, and private consultants may be able to assist planners by advising them of pertinent data and where those data can be obtained. Interpretation of the data for an evaluation of seismic risk commonly requires a team of planners, geologists, and soil and structural engineers.

\section{INTRODUCTION}

Urban planners and public officials in California and in many other parts of the United States have become increasingly concerned about the possible effects of future earthquakes and how to minimize damage and reduce loss of life. Interest in seismic hazards has increased further after the adoption in 1971 by the California legislature of an amendment to the State Planning Law that includes a "Seismic Safety Element" as a mandatory element of the General Plan (Chapter 150, Section 65302 of the Government Code). This requirement, along with concerns for other geologic hazards and for conservation of natural resources, has focused the attention of planners on the contributions that geology and other earth sciences can make to the planning process.

This report outlines those earthquake-induced geologic conditions that could be hazardous, the type of problems they may pose, how information can be obtained to assess the degree of hazard, and some possible implications to land use. The availability of earth-science information, of itself, does not insure that it will be used (Mader, 1972, p. 78). However, where it exists and the citizenry is aware and concerned, significant steps can and have been taken to amend land-use policies to reflect seismic and geologic conditions even without legislative encouragement (City of Hayward, Planning Commission Subcommittee on Land Use and Development Regulations, 1972).

\section{ACKNOWLEDGMENTS}

This report is modified from a draft report prepared by the senior author on behalf of the Land 
Use Planning Advisory Group to the California Joint Legislative Committee on Seismic Safety. The draft report was designed to provide guidelines for the preparation of a seismic safety element to city and county general plans. Both reports benefit greatly from the advice and comments of several members of the Land Use Planning Advisory Group, particularly those of its chairman, Mr. George G. Mader. Several city and county planners and earth-science consultants in the San Francisco Bay area also offered valuable suggestions.

Except where noted, all photographs are from the files of the U.S. Geological Survey.

\section{SEISMIC HAZARDS AND IMPLICATIONS FOR LAND USE}

Earthquakes commonly give rise to various geologic processes that may cause severe damage to structures and death to people in them. These processes include surface faulting, ground shaking, associated ground failure, generation of large waves in bodies of water, and regional subsidence or downwarping.

These seismic hazards vary widely from area to area, and the level of hazard depends on both geologic conditions and the extent and type of land use. This section describes geologic conditions that may contribute to seismic (italicized words are defined in the glossary) hazard, how to determine their significance in a given area, the level of data desirable for land use decisions, and some possible implications for land use.

\section{SURFACE FAULTING}

The earth is laced with faults-planes or surfaces in earth materials along which failure has occurred and materials on opposite sides have moved relative to one another in response to the accumulation of stress. Most of these faults have not moved for hundreds of thousands or even millions of years and thus can be considered inactive. Others, however, show evidence of current activity or have moved recently enough to be considered active, that is, capable of displacement in the near future. Any fault movement beneath a building in excess of an inch or two could have catastrophic effects on the structure, depending upon design and construction and the shaking stresses the structure undergoes at the same time (fig. 1). Therefore, it is important to know not only which faults may move but how they may move.

The definition of what constitutes an "active fault" may vary greatly according to the type of land use contemplated or to the importance of the structure. For example, the Atomic Energy Commission regards a fault as active or "capable" with respect to nuclear reactor sites if it has moved "at or near the ground surface at least once in the past 35,000 years," or "more than once in the past 500,000 years" (Atomic Energy Commission, 1971). A definition for purposes of town planning in New Zealand defines as active, any fault on which movement has taken place at least once in the last 20,000 years (Town and Country Planning Branch, Ministry of Works, 1965; originally published as 1,000 years by typographical error). Commonly, faults are regarded as active and of concern to land-use planning when there is evidence that they have moved during historic time or, through geologic evidence, there is a significant likelihood that they will move during the projected use of a particular structure or piece of land. Because geologic evidence may be lacking, obscure, or ambiguous as to specific times of past movement, geologists may be able to estimate relative degree of activity only after a regional analysis that may extend far beyond the locality under consideration. Such analysis may be based on historic evidence of fault movement, seismic activity (occurrence of small to moderate earthquakes along the fault trace even though not accompanied by obvious fault movement), displacement of recent earth layers (those deposited during the past 10,000 years), and presence of geomorphically young, fault-produced features (scarps, sag ponds, offset stream courses, and disruption of manmade features such as fences and curbs) (figs. 2, 3, 7, 8).

Knowing that a particular fault is active, however, is only part of the problem. The other part is predicting the likely location of fault ruptures during the next significant earthquake. Geologists generally accept the premise that the next rupture will probably occur along the fault trace that ruptured last, especially if there is evidence of repeated earlier movements on the same fault trace (fig. 3 and Wallace, 1968a, p. 17). However, movement seldom is limited to a single fault surface throughout the lifetime of a fault system such as the San Andreas. In many places tens or even hundreds or thousands of individual fault surfaces make up the San Andreas in a zone varying in width from a few hundreds to many thousands of feet. Any individual fault surface may have ruptured at any time during the last $\mathbf{4 0}$ million years 


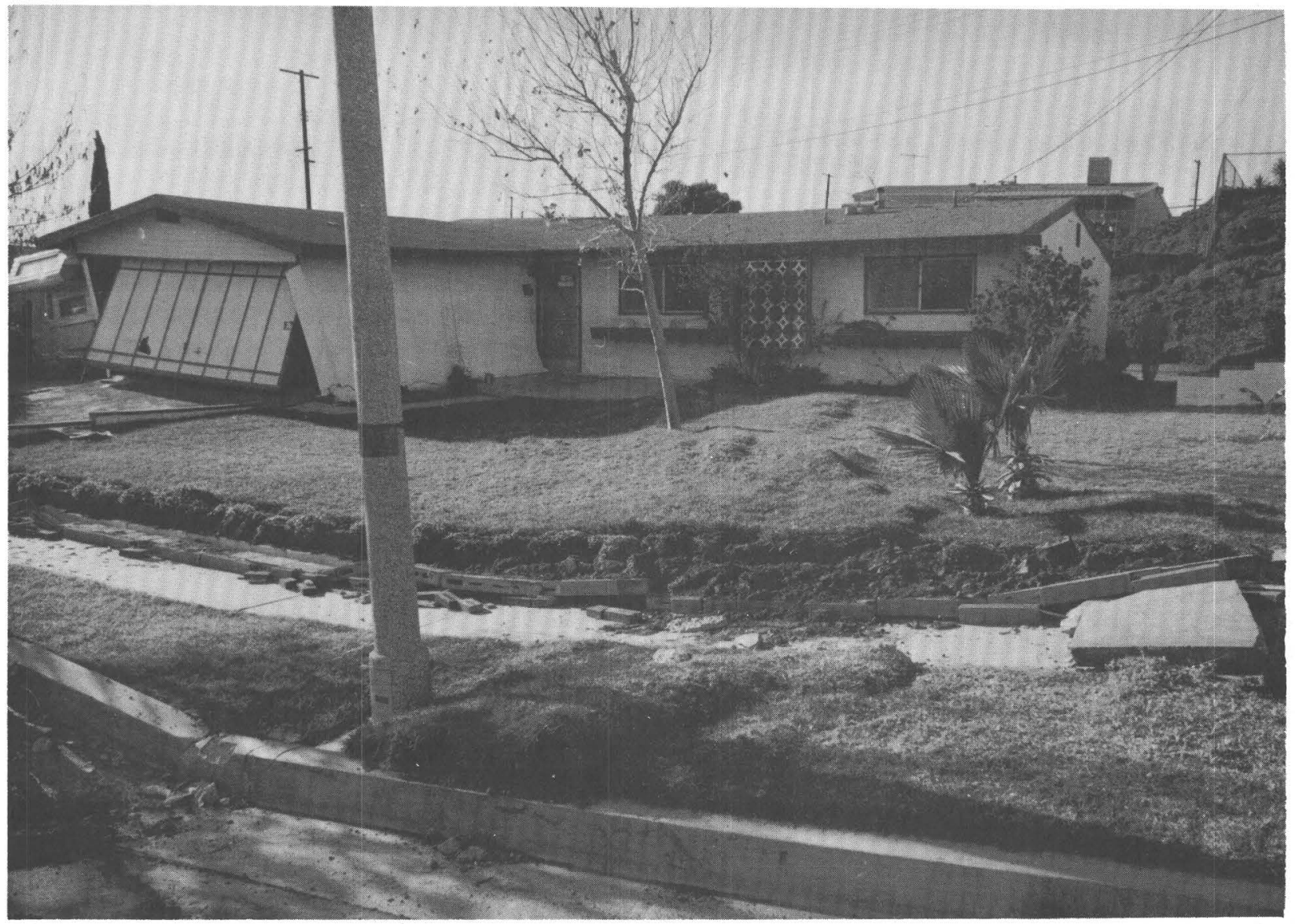

Figure 1.-House damaged by displacement along a thrust fault during the San Fernando earthquake, February 1971.

or so that the fault has been active. It is speculated, however, that most of these surfaces probably have not moved in millions of years, and only infrequently may a new rupture surface develop or is fault movement transferred from one part of the fault zone to another.

Faults that commonly produce significant displacement (more than several inches at a time) often have related branches that diverge from the main fault but usually have less movement along them (fig. 4). They may also have secondary faults that are not directly or obviously connected physically to the main fault trace. Secondary faults are usually nearby (within hundreds of feet of the main rupture), but they may extend as much as several miles away. As with branch faults, displacement along secondary faults is usually only a fraction of that along a main fault.

The amount of displacement that can occur during a single earthquake can be related in a general way to the total length of a fault. The longer the fault, the greater the potential for a great earthquake and the greater amount of displacement likely (fig. 5 and Albee and Smith, 1967, p. 432; Bonilla, 1970, fig. 3.16). The maximum displacement ever recorded during a single earthquake is about 42 feet of vertical displacement (Bonilla, 1970). Horizontal movement of as much as 20 feet occurred along the San Andreas fault in 1906 (Bonilla and Buchanan, 1970).

In addition to the location and amount of displacement, the sense of movement is extremely important in estimating the amount and type of damage that might be produced. This was evidenced by the great damage over faults during the moderate (magnitude 6.6) San Fernando earthquake which produced a reverse or thrust fault movement (fig. 6a); movement occurs along a similar plane, but in an opposite direction on the normal (fig. 6b) Wasatch fault in Utah. Left-lateral movement(fig. 6c). and right-lateral movement, which is common to the San Andreas fault, proba- 


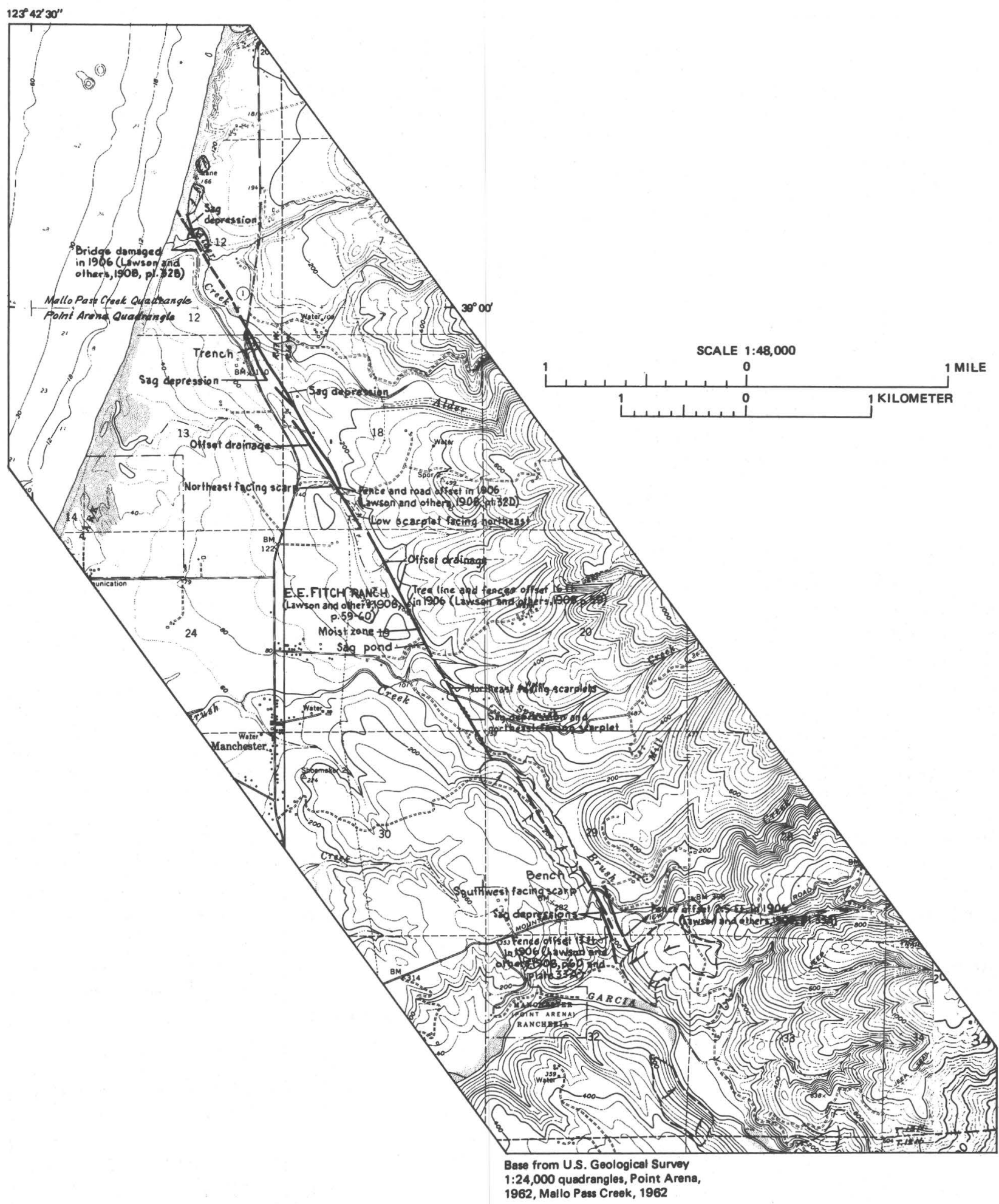

Figure 2.-Map of recently active breaks along the San Andreas fault near Point Arena, Calif., illustrates kinds of fault-produced topographic features and the linearity of surface features which commonly result from faulting. (From Brown and Wolfe, 1970, sheet 1 of 2.) 


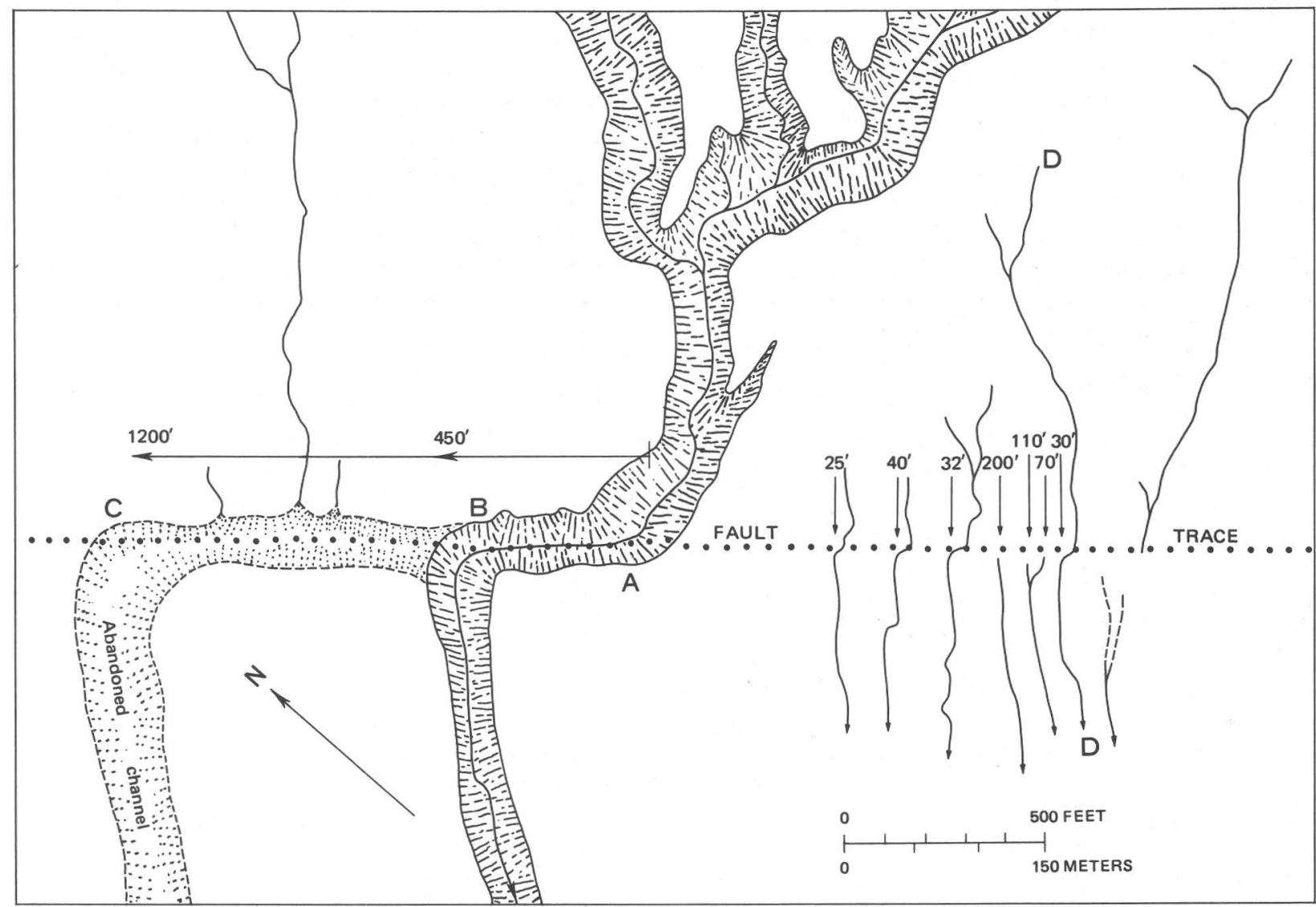

Figure 3.-Progressive lateral shifting in stream alinement due to repeated displacement along a single trace of the San Andreas fault. The major stream channel has been deflected 450 feet from A to B; earlier displacements are suggested by the beheaded stream segment at C, 1,200 feet from A. The small stream channel at D displays a series of offsetsrepresented by one deflection and three abandoned downstream segments-measuring 30, 70, 110, and 200 feet. (From Wallace, 1968a, fig. 8.)

bly are less potentially damaging to most structures than normal or thrust faulting.

Not all surface faulting need be rapid nor need it occur during major earthquakes. Imperceptibly slow movement, called "fault creep" (fig. 7), occurs along the Hayward, Calaveras, and some other faults and may be accompanied by microearthquakes. Similarly, not all deformation of the earth's surface produces fault displacements. Strains in the earth deform the rocks until their strength is exceeded and they rupture, producing the earthquake. Accompanying this bending, however, is a certain amount of plastic deformation (fig. 8). Both rupture and plastic deformation commonly occur along active fault zones and may be sufficient to damage or destroy structures over particularly strongly deformed rocks. Earthquakes deep within the earth may result from rupture of deeply buried rocks but without fault displacement at the ground surface, although the surface rocks may be deformed(fig.6d). This may have occurred along a part of the NewportInglewood fault zone where movement along the fault during the last 10,000 years or so has merely caused a permanent flexuring or bending of the surface rocks (Castle, 1966). Recent surface displacement is not characteristic of faults in the Eastern United States.

\section{METHODS FOR ASSESSING FAULT HAZARDS}

The above discussion focuses on the kinds of problems that need to be assessed and gives a clue as to why specific, quantitative predictions on the exact location, nature, amount, and time of movement along a fault can seldom be provided. What the geologist can say and the degree of confidence behind the statements are based on the type and number of investigations that form the basis of the judgments, not only within the area of concern but also along an entire fault system. The following 

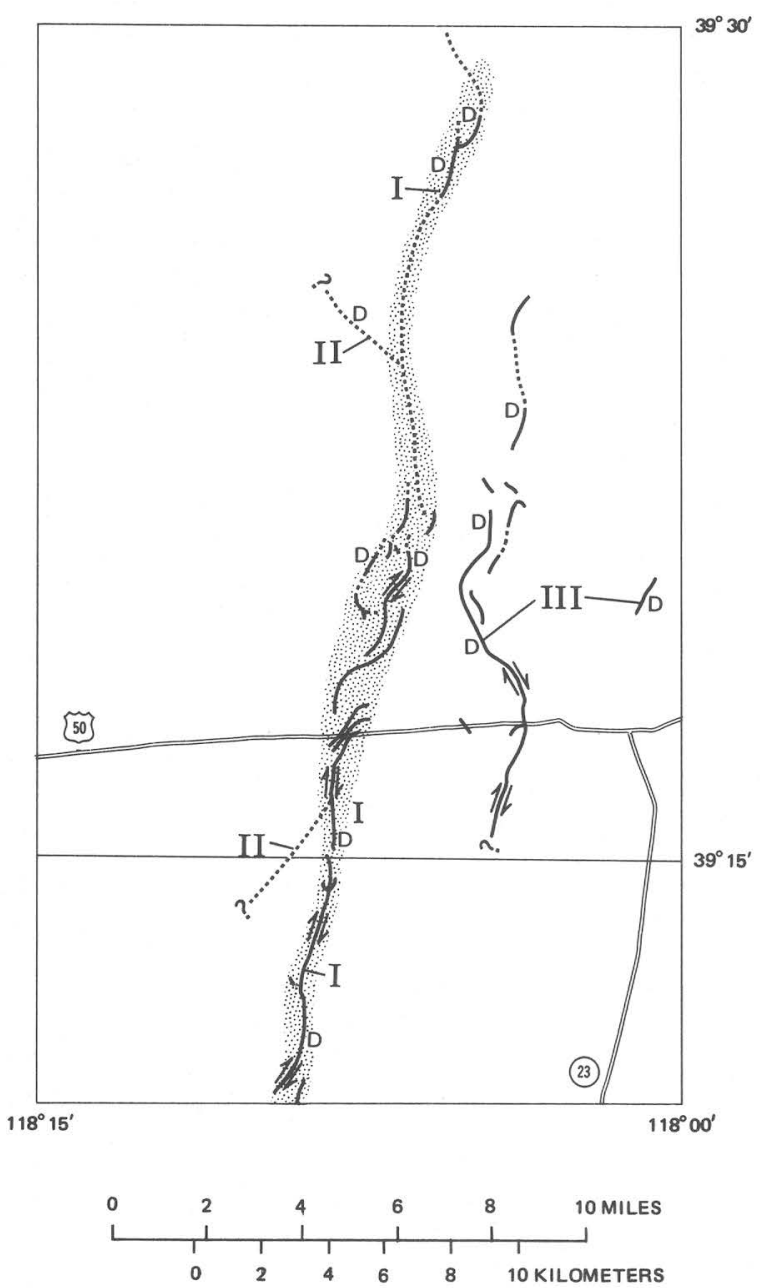

Figure 4.-Map showing main fault traces (I), branch faults (II), and secondary faults (III). Dashed lines indicate uncertainty of specific fault locations. (From Bonilla, 1970, fig. 3.4.)

paragraphs list some of the principal data and the judgments they may allow. A later section (p. 28-29) lists in greater detail the kinds of earthscience data needed and their purpose.

Background information of particular value includes: geologic maps (at scales of 1:24,000 to a maximum of 1:250,000), detailed geologic mapping of particular problem areas (at scales of 1:6,000 or larger), long-term records from numerous, nearby seismograph stations (fig. 9), and topical studies of faulting, which may include interpretation of aerial photographs, examinations of trenches and bore holes, age dating of samples, and geophysical surveys. Lacking one or more of these categories of background studies may seriously limit the geologist's predictive capability.

These studies should lead to knowledge about

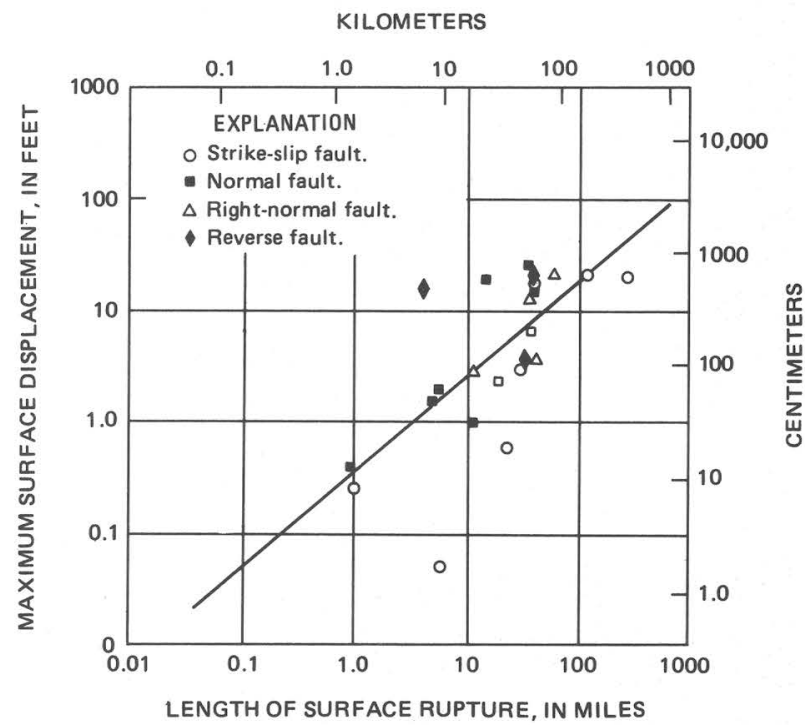

FIgURE 5.-Logarithmic plot relating maximum amount of surface displacement to the length of surface rupture on the main fault trace. Points record known historic surface faulting accompanying earthquakes in the continental United States and adjacent parts of Mexico. (From Bonilla, 1970, fig. 3.17.)

the location, total length, and width of the active fault zones and all the likely active traces. They should assess the sense of movement (horizontal or vertical) and the maximum amount expectable. The amount and nature of possible deformation should also be assessed within and adjacent to the fault zone. The character of faulting and deformation within each type of earth material at the surface should also be evaluated-do they break sharply along a single plane, do they shear over a wide zone, or is the movement absorbed by adjustments of individual grains with no definable fault trace?

The data collected for an evaluation of hazard from surface rupture should be sufficient to allow the formulation of a design earthquake-that is, the maximum expectable earthquake magnitude, general depth of energy release, and general frequency of occurrence for each fault zone capable of generating an earthquake.

\section{IMPLICATIONS FOR PLANNING AND LAND-USE CONTROLS}

With the above information, the planner, in consultation with the geologists, seismologists, and engineers, can assess the consequences of surface rupture and deformation to different types of existing, planned, or possible land use (if uncontrolled or under existing regulations) in the areas subject 


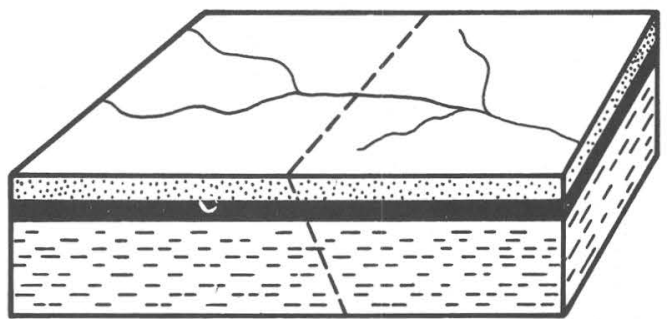

Earth block before movement
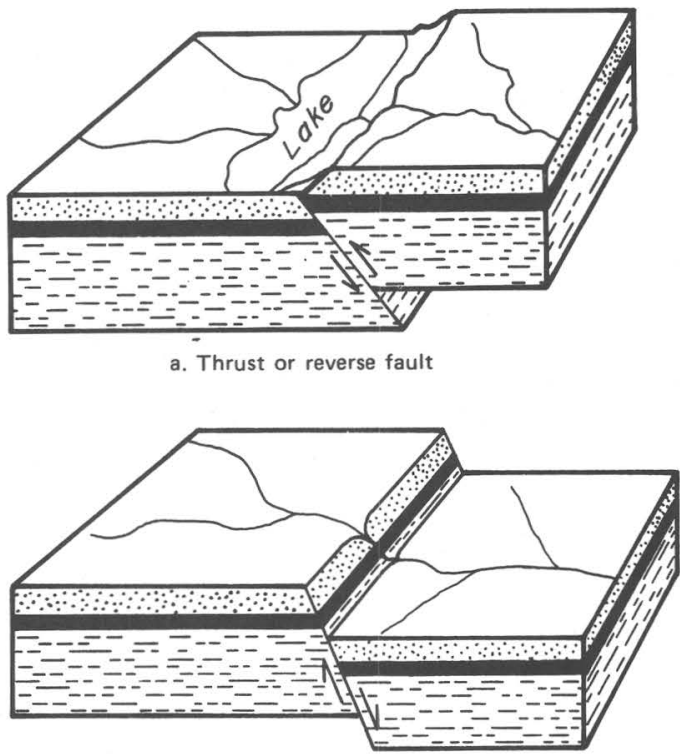

b. Normal fault

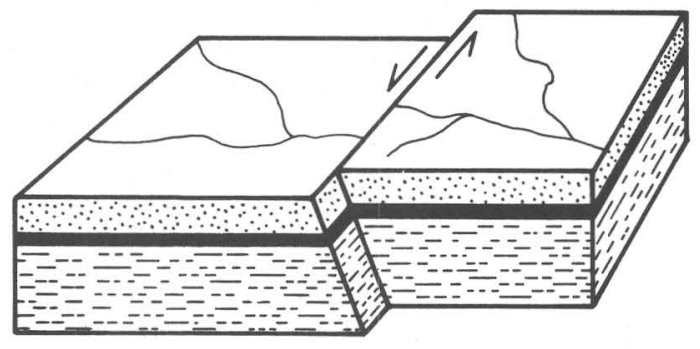

c. Left-lateral fault

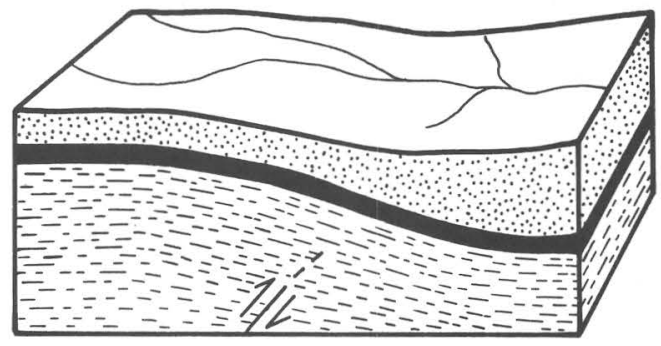

d. Monoclinal fold caused by faulting at depth

Figure 6.-Examples of some types of fault displacement and earth flexure. (Modified from Longwell and others, 1949.)

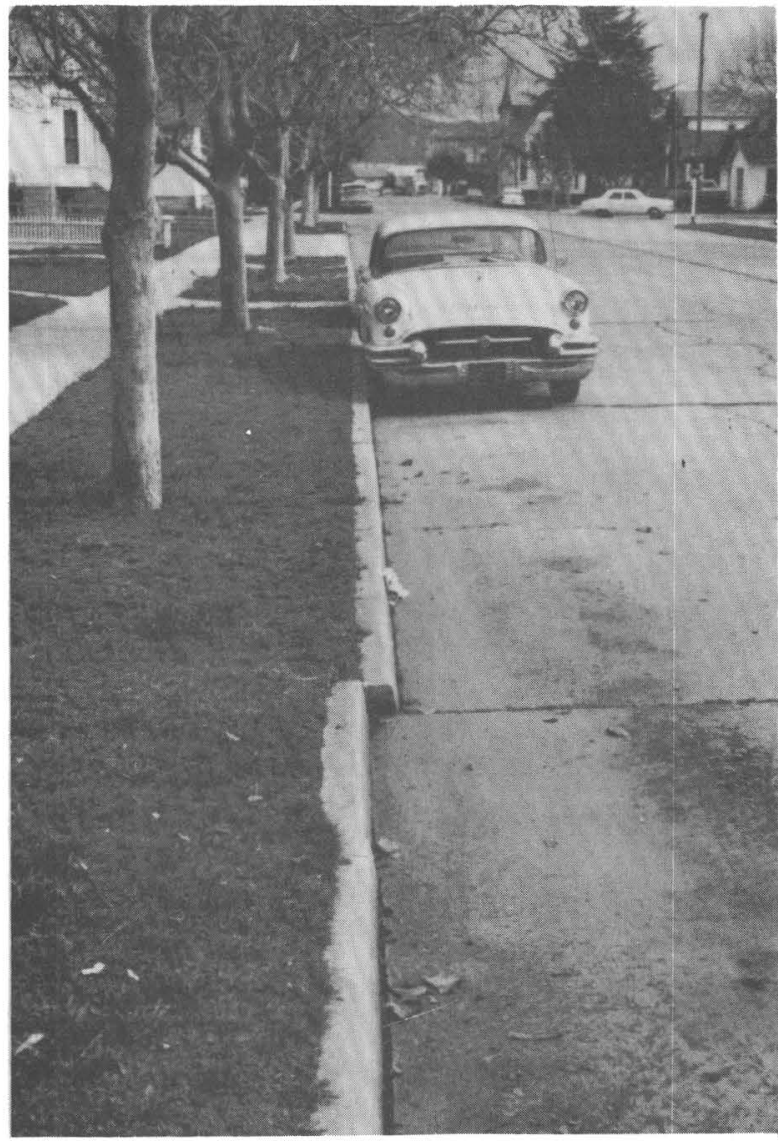

Figure 7.-Curb displaced by fault creep on the Hayward fault. This type of movement is usually imperceptibly slow and generally is not accompanied by felt earthquakes.

to ground displacement. Where these consequences suggest unacceptable levels of damage to property or loss of life, alternative land uses that would be compatible with fault rupture, and with adjacent and regional land uses, should be recommended. One alternative that might be considered would be to allow the planned use but to impose controls on the method of construction and its location so that an undue hazard would not occur. Implementation regulations might call for establishing a fault hazards easement (Mader and others, 1972) that would require a setback distance from the active fault traces (fig. 10). The amount of setback might differ with the type of faulting and deformation expected. It might also vary with respect to the character of individual faults and even segments of a single fault as well as with the knowledge or lack thereof of the fault zone and the structure or development being considered. Thus the more critical the structure, the greater the likely setback limit. 


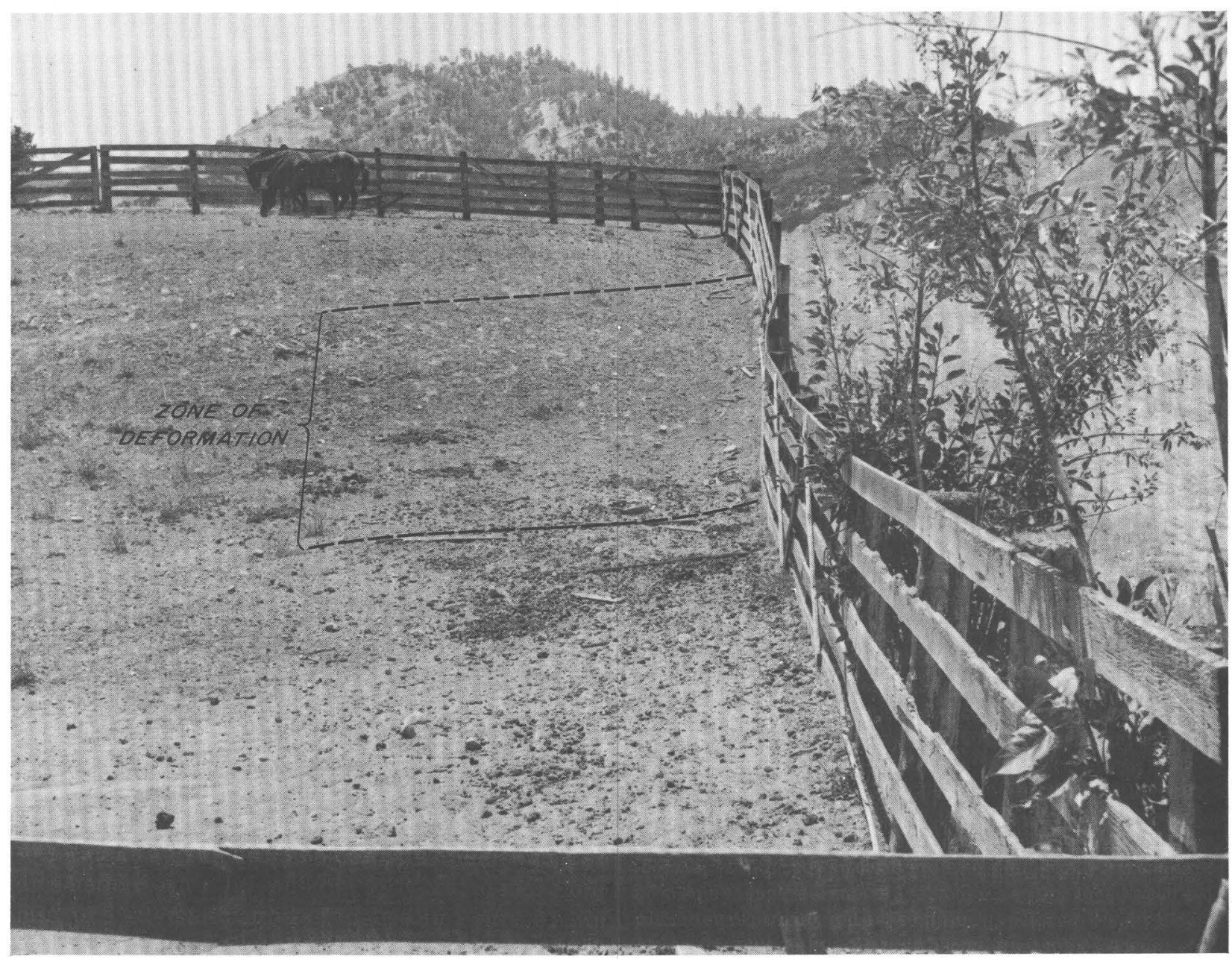

FIGURE 8.-Corral fence showing evidence of continuing deformation in a zone of the San Andreas fault, which results from strains that bend the rocks without significant earthquake activity. The distant portion of the fence has been offset about 21 inches to the right of the near portion. (From Brown and Wallace, 1968, fig. 4.)

In addition to adoption of a fault hazards easement, similar to a scenic easement, jurisdictions might consider adoption of "fault hazard zoning" or the broader "geologic hazard zoning," which would include such hazards as landslides and floods as well as faults. Such zoning might override conventional zoning, prohibit human occupancy, require a land use compatible with both the hazard and adjacent uses, or stipulate minimum site investigative and safety standards. Certainly, any development to be considered within, or immediately adjacent to, an active fault zone should require geologic studies to demonstrate that the proposed construction would conform to standards of community safety and that an undue hazard to life and property would not ensue.

Alternatively, prohibition of all uses other than those essential to the public welfare (utility and transportation facilities) could be considered in areas of extremely high hazard. Certain types of land use are completely compatible with the high level of hazard attendant to areas such as the San Andreas fault zone. Some of these include open space, recreation areas (including golf courses, nurseries, horseback riding, bike trails, and so on), cemeteries, freeways (but not interchanges), parking lots, and solid-waste disposal sites (under some conditions) (fig. 11).

Where development already occurs within active fault zones, jurisdictions can adopt policies leading to the removal of critical engineering structures on the most accurately located active fault traces. Nonconforming building ordinances should be considered that could require eventual removal of structures in the greatest danger, starting with those that endanger the greatest number 


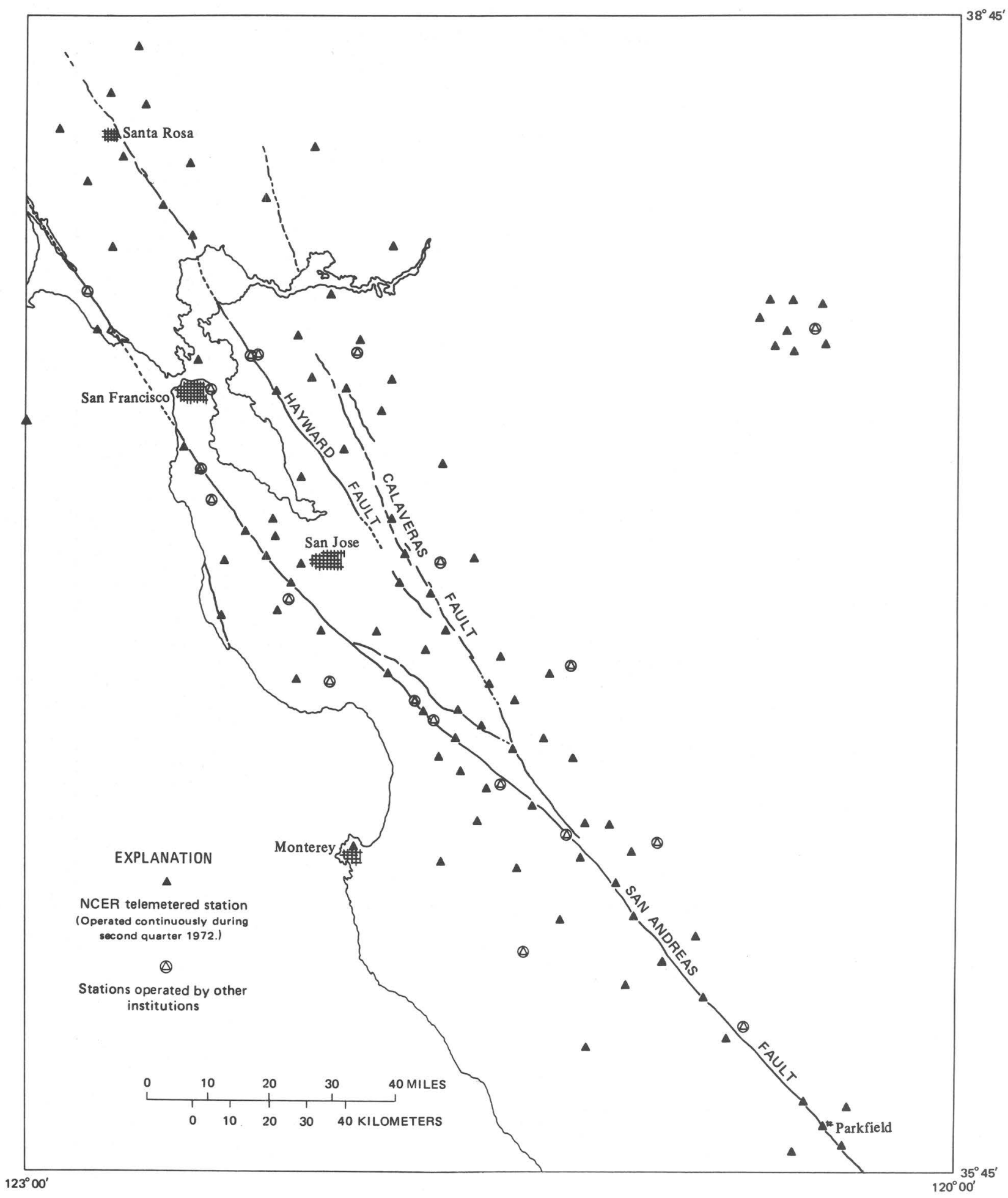

FIGURE 9.-Map showing the location of seismograph stations in a closely spaced USGS instrument network in central California. These stations provide accurate data on the location, frequency, and size of earthquakes occurring within the area and aid in defining causative faults. 


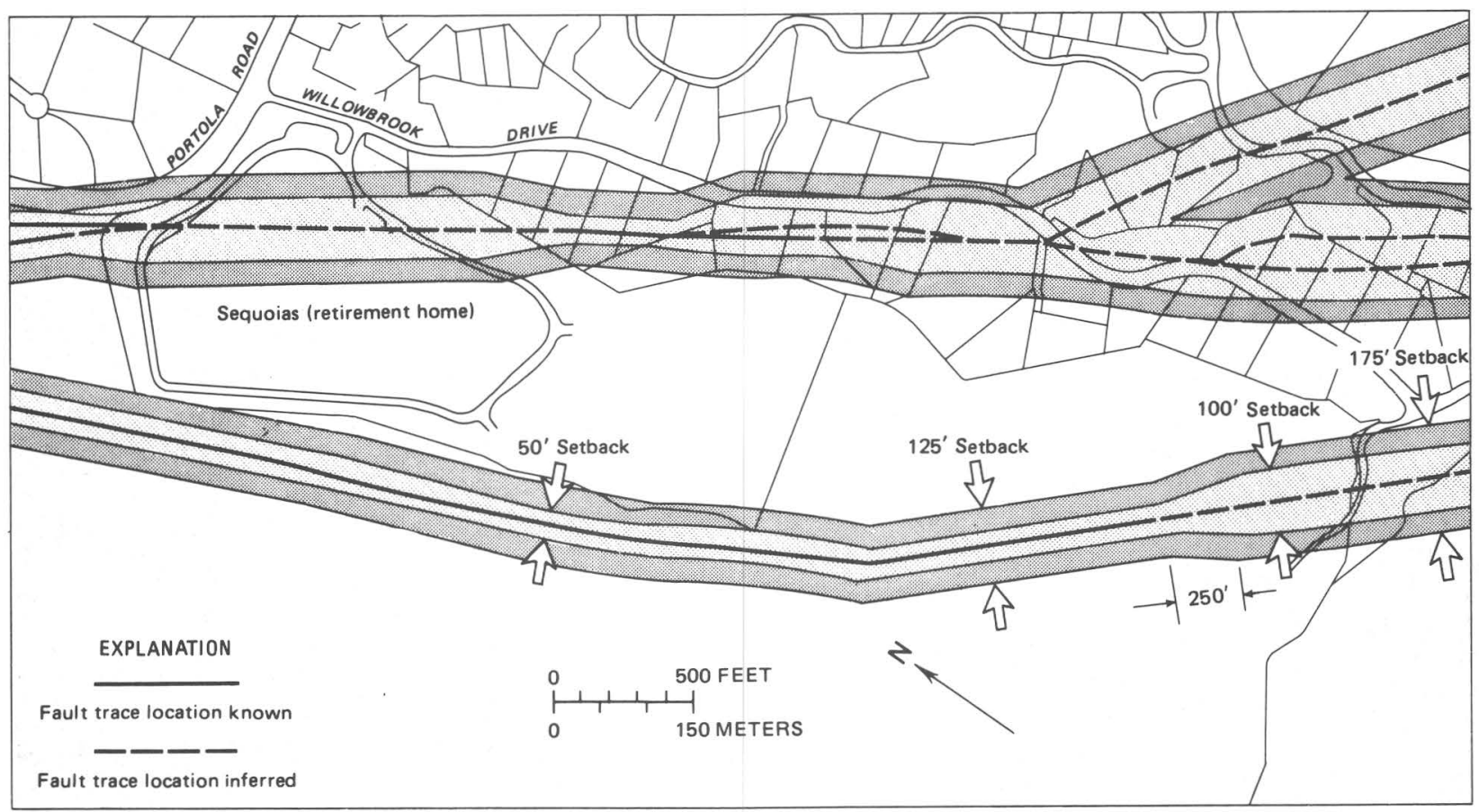

Figure 10. Example of minimum easements required for building setbacks from active fault traces by town ordinance in Portola Valley, Calif. All new building construction is prohibited within the 100 -foot wide, lightly shaded zone (50 feet on each side of the well-located portion of the San Andreas fault); structures with occupancies greater than single

of lives-schools, hospitals, auditoriums, office buildings and apartment houses, followed by commercial buildings, and perhaps eventually by single-family residences (fig. 12). The nonconforming building ordinances might be based on either an arbitrary time schedule or the expected lifetime of the structures involved. Other innovative options for control of development include tax incentives and adoption of urban renewal policies that would encourage removal of hazardous structures and that would prohibit reconstruction in hazardous areas after earthquakes or other natural disasters (Diplock and Nichols, 1972).

\section{GROUND SHAKING}

Earthquake-generated ground shaking, in many instances, causes the most widespread earthquake damage. However, ground shakingwhat most people and structures react to during an earthquake-is one of the most difficult seismic hazards to predict and quantify. Data from past earthquakes have shown that the intensity of ground shaking can be several times larger on family dwellings are required to be 125 feet from the fault trace (dark shading). Where location of the fault trace is less well known, the more conservative setbacks of 100 feet for single family residences and 175 feet for higher occupancies are required. (Modified from Mader and others, 1972, fig. 5.)

sites underlain by thick deposits of saturated sediments than on bedrock. Consequently, the greatest losses, resulting solely from shaking, may occur where tall structures are built on thick, relatively soft, saturated sediments (fig. 13) and the least where they are built on firm bedrock (Wallace, 1968b, p. 67).

In addition to the amplification effects of local geologic deposits, the amount of ground shaking at a particular site depends on (1) characteristics of the earthquake source (for example, magnitude, location, and area of causative fault surface) and (2) distance from the fault. To anticipate the severity of ground shaking likely to occur at a site, each of these factors must be taken into account. The extent of shaking damage is also dependent partly on the structural integrity of buildings before the earthquake. (See Page and others, 1972, for a discussion of ground motion values used in the seismic design of structures.)

Characteristics of the earthquake source and distance can be crudely estimated from the seismic history of the area and detailed geologic mapping 


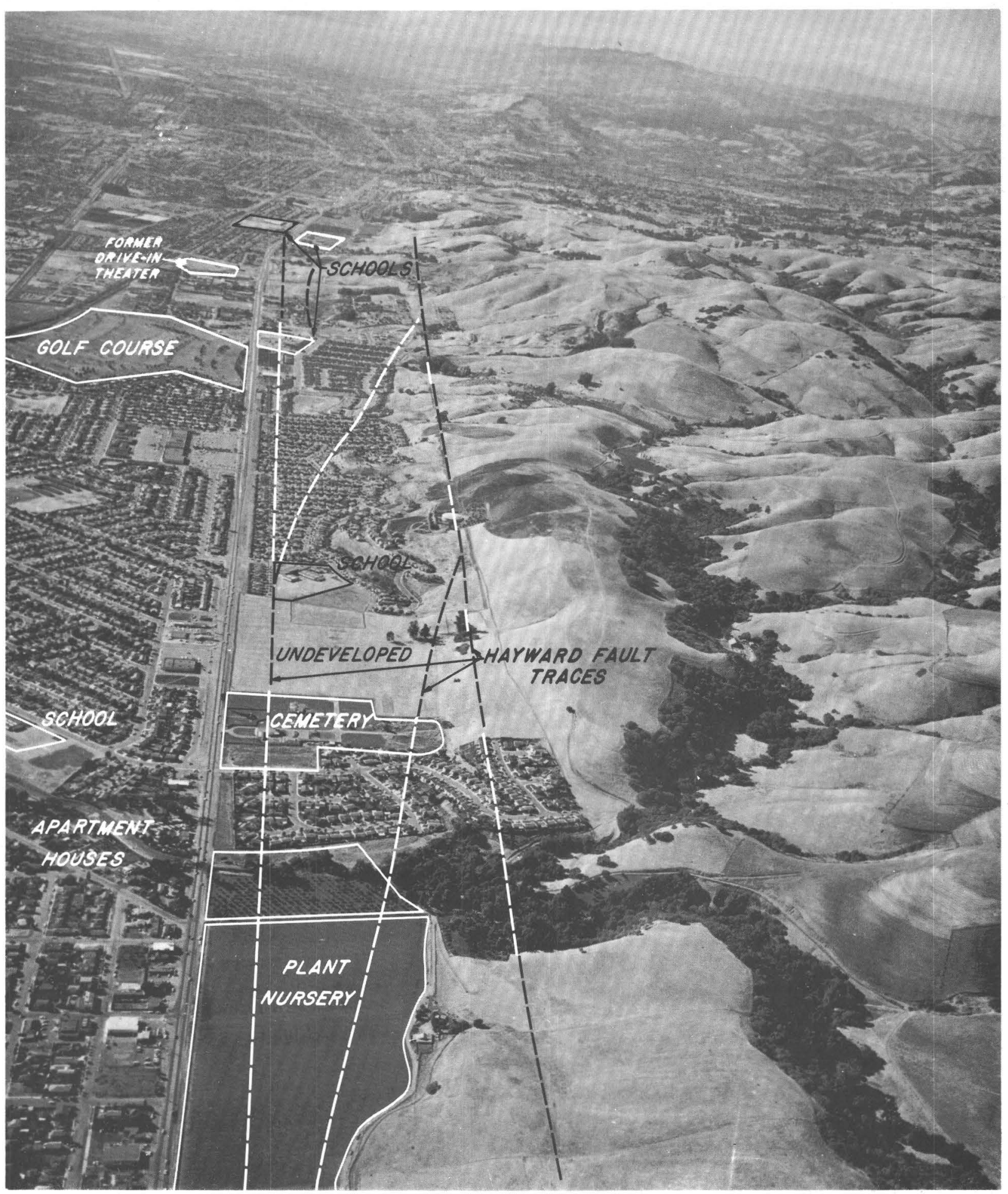

FIGURE 11.-View showing approximate location of fault traces within a părt of the Hayward fault zone, some of which ruptured during the October 21, 1868 earthquake (Radbruch, 1967). The plant nursery, undeveloped open space, freeway, and cemetery are land uses most compatible with the hazards posed by this active fault. Other such uses might include drive-in theater, golf course, riding stable, and other recreational activities. 


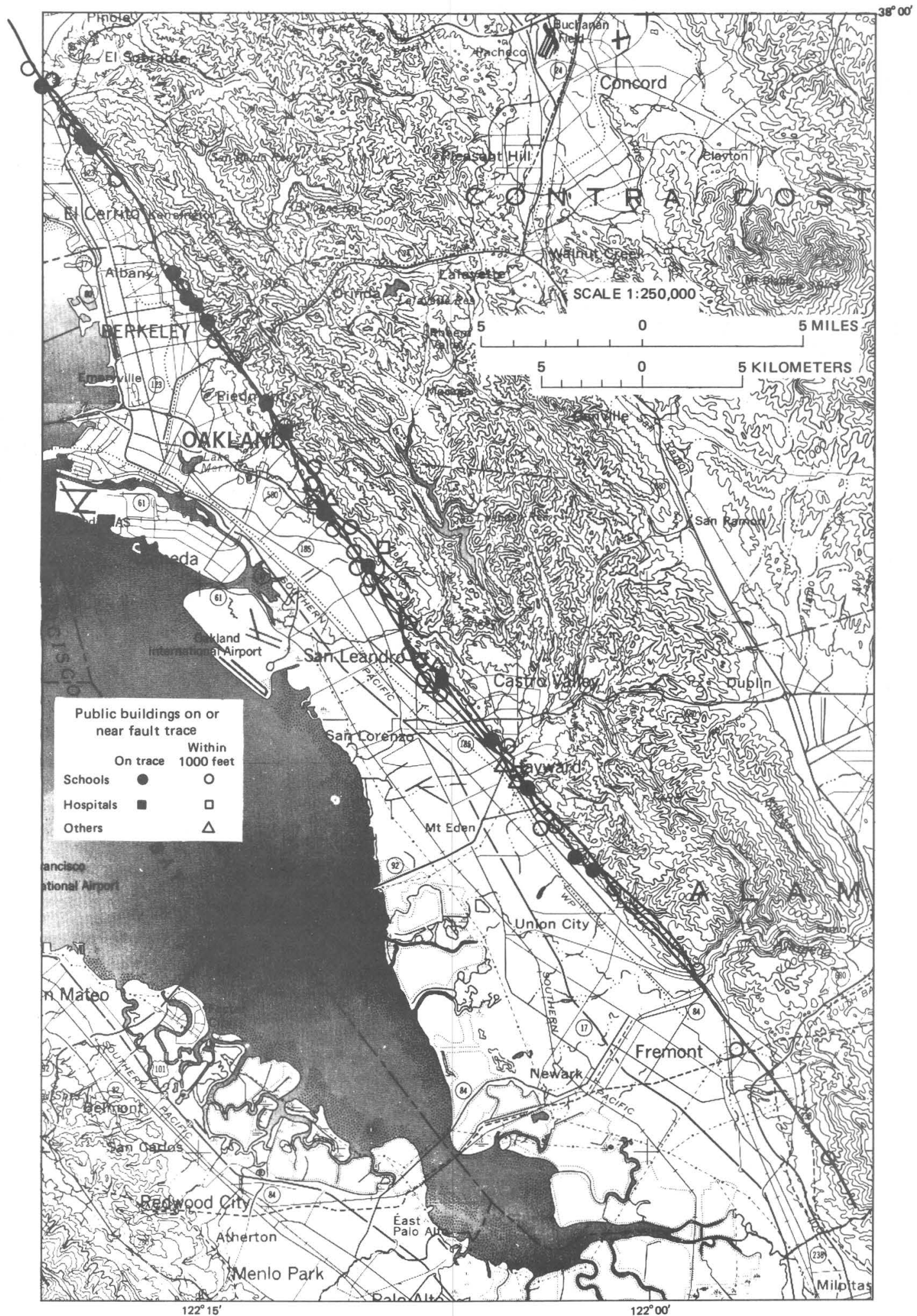

FIGURE 12.-Schools, hospitals, and other public buildings on or near traces of part of the Hayward fault. Ordinances declaring such buildings as nonconforming structures could lead to their eventual relocation to areas with less adverse geologic conditions, thereby reducing potential loss of lives and property. (From Alquist, 1971, p. 17.) 


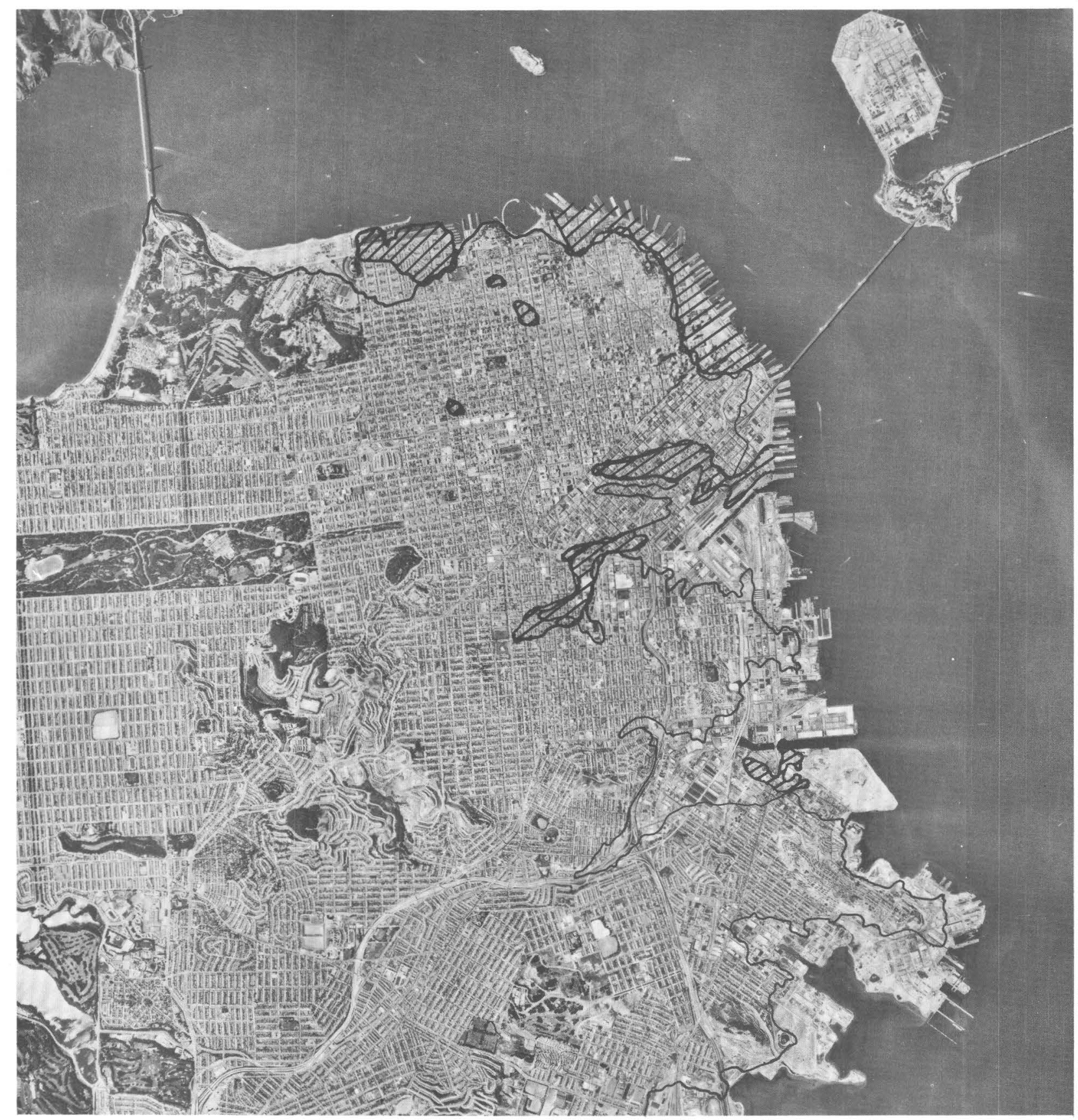

Figure 13.-Aerial photograph of San Francisco showing relationship of greatest damage in the 1906 earthquake (patterned) to areas of former bay and marshlands (landward edge shown by solid line).

studies. The amount of data available for such estimates varies widely for different parts of the country, but in some areas (for example, the San Francisco Bay area) detailed research programs are providing data expressly for this purpose. With such estimates, it then becomes possible to ex- amine potential variations in shaking due to variations in local geologic conditions.

METHODS FOR ASSESSING SHAKING HAZARDS

Earth-science data bearing on possible effects of ground shaking are varied and often incomplete. Starting with a prediction of a design earthquake 
(see p. 6), an evaluation of shaking intensity can be made at the ground surface that reflects the effect of the local geology (rock, firm soil, and thick wet soil) on modifying the earthquake motion. One useful tool to assess potential building damage from knowledge of ground conditions is to relate the fundamental period of a building to the ground on which it rests. A damaging resonance commonly develops where the fundamental building period coincides with the natural period of the ground. In a very general way, the fundamental building period is related to its height or number of stories and that of the ground to its firmness, thickness, and degree of saturation. Taller buildings have a longer fundamental period ( $2 \mathrm{sec}$ or more) and are subject to greater damage where they stand on ground with a long fundamental period (fig. 14). Conversely, 1- or 2-story buildings with a short fundamental period may be more vulnerable on firmer ground.

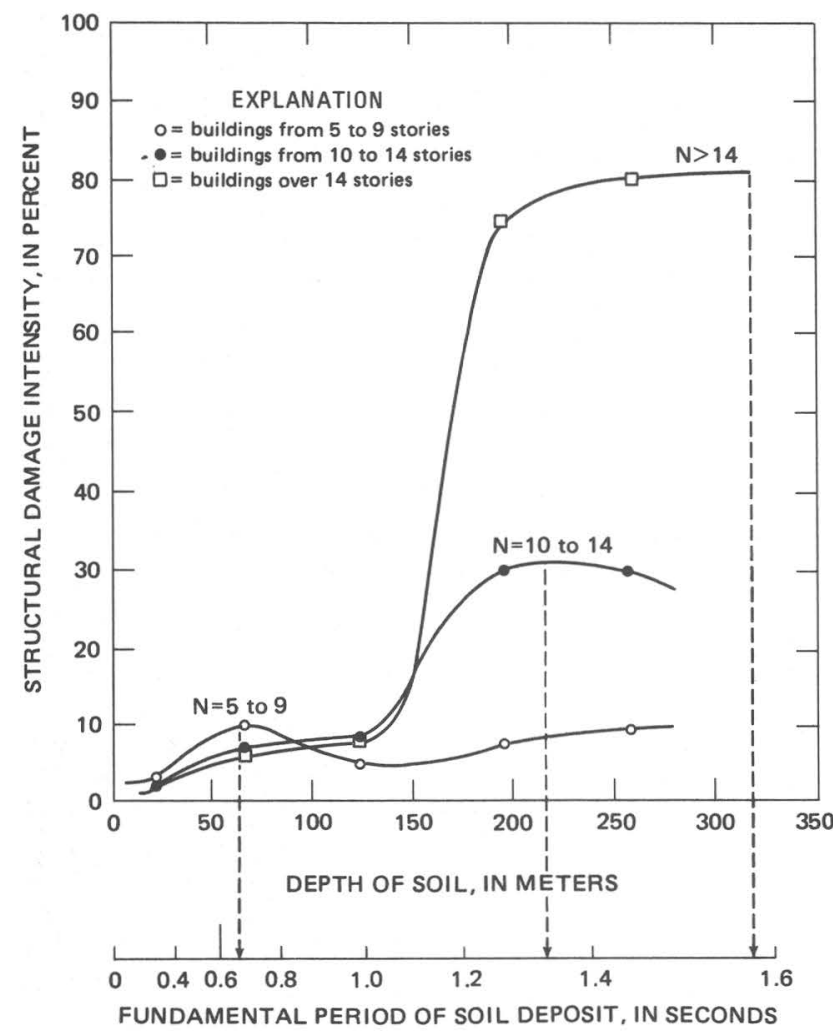

Figure 14.-Structural damage intensity for different height buildings related to depth of soil and computed fundamental period of soil deposit. $\mathrm{N}=$ number of stories. Where the fundamental period of a soil deposit is short (between 0.6 and 0.8 sec), the greatest damage will occur to buildings from five to nine stories tall. With longer soil periods, damage intensity to higher structures increases. (From Seed and others, 1972, fig. 12.)
Ideally, therefore, one means of expressing ground shaking is in terms of the likely response of specific building types-wood frame residences, single-story masonry structures, low-rise (3- to 5 -story), moderate-rise (6- to 15-story), and highrise (more than 15-story) buildings. Each of these building classes, in turn, can be translated into occupancy factors and generalized into land-use types.

Although we cannot presently predict when, where, or how great the next earthquake will be, several qualitative approaches can be used for planning purposes to anticipate where ground shaking will be most severe. Selection of any one approach depends upon the use to which it may be put, the money available, and recent improvements and sophistication in methodology.

(1) Correlation of earthquake effects with the general firmness of rock and soil is an empirical technique based on examination of damage from numerous historic earthquakes. Because few earthquakes have occurred in areas where stringent building codes and modern construction standards are in effect, this correlation requires careful interpretation. Some examples of high shaking damage include areas of thick, soft sediments in downtown San Francisco, Santa Rosa, and San Jose during the 1906 San Francisco earthquake and parts of Caracas, Venezuela, during a 1967 earthquake. Areas of firmer soil and rock much nearer the epicenter during both earthquakes suffered considerably less damage.

Areas with relatively different shaking characteristics commonly can be determined from most good geologic maps that distinguish between different kinds of bedrock and unconsolidated deposits. Although such maps may not explicitly rank units by degree of firmness, give total sediment thickness, or assess degree of saturation, most geologists may be able to make such interpretations on the basis of a knowledge of the age of the geologic units and some additional engineering field and test data (Nichols and others, 1972). Any determination of the fundamental ground period requires knowledge of sediment thickness and measurements of the shear velocity of the geologic units. Maps prepared on this basis should only purport to serve as a general guide to relative ground shaking effects.

(2) Intensity maps, based on the Modified Mercalli, or a similar intensity scale, have been made in many areas from damage studies of past earth- 
quakes. In a general sense, intensity is a function of ground conditions and distance from the epicenter. Lower numbers on the scale indicate less severe shaking and are based on what people feel; intermediate numbers are assigned according to the type and amount of building damage sustained (without regard to age of construction), and higher numbers principally to secondary geologic effects (ground failure).

Where intensity maps, based on previous earthquakes, do not exist or do not reflect the maximum expectable earthquake, they can be prepared using a recently developed method. Intensity increments, commensurate with local ground conditions, are added to a base intensity computed for a specified design earthquake. This technique has been used extensively in the Soviet Union (Barosh, 1969) and has been applied to the State of California (Evernden and others, 1972).

Analyses based on (1) and (2) provide only general qualitative guidelines for ground shaking and earthquake-resistant design. They do not provide quantitative estimates of ground shaking for use in estimating engineering design parameters. Nor do they necessarily distinquish the effects on structures due solely to ground shaking from those due to ground failure. They can be made more useful, however, by applying empirical relations from parallel studies of ground motion characteristics determined from distant natural or manmade microseismic events (Borcherdt and others, 1972). Such studies provide a measure of amplification effects on different kinds of ground at low strain levels (fig. 15). Because the amplification effects from small ground motions are generally linear, while those from strong motion may be nonlinear, such measurements cannot be extrapolated directly to large earthquakes. Most soils and rocks have elastic properties up to certain levels of strain; beyond these levels, they deform plastically or rupture. Consequently, as the strain increases, the ground motion increases up to a point that varies from one ground condition to another. Strain increases that result from very large amounts of energy release, as in a great earthquake, probably are not matched by comparable increases in ground motion. Instead, the strain exceeds the strength of the earth materials that yield, damping the motion.

Theoretical models to predict surface ground motion have existed for many years. Not until relatively recently, however, have enough obser- vations been available from earthquakes and from in situ ground measurements to provide reliable data to use in the models and on which to base an evaluation of the validity of the models (Seed and Schnabel, 1972). Because theoretical modeling techniques require detailed knowledge of geologic and soil conditions and assumptions as to the character of the bedrock motion, their use has been fairly expensive and limited as a predictive tool to anticipate the effects at a single site-usually one to be occupied by a critical structure. These techniques are still in the developmental stage and have not yet won complete acceptance among the experts (Hudson, 1972, p. 41 and Newmark and others, 1972 , p. 115-117). Increasing sophistication in analysis, along with expanding knowledge of earthquakes and their mechanism, may soon generate more widespread acceptance and perhaps eventually allow their application to general land-use problems.

In the meantime, the very broad generalized approach in characterizing the firmness of the ground appears to be adequate to assess the gross effects of ground shaking for general planning purposes. Where intensity maps representative of expectable earthquakes exist or can be prepared by modern techniques, they would be valuable for general plan purposes and for specific plans such as an urban renewal program or a large-scale redevelopment proposal. On the other hand, builders of proposed structures that are critical or that will have high occupancies might be required to have a dynamic analysis prepared of the structure and site as a means of assessing their safety and design.

\section{IMPLICATIONS FOR PLANNING AND LAND USE}

Seldom can a structure, without regard to its height, be declared inappropriate if it is carefully designed specifically for a given site. Nevertheless, as a broad planning tool, knowledge of expectable ground shaking effects, in combination with other considerations, could lead to low-density land uses in some areas. Elsewhere, such knowledge can lead to the adoption of building code provisions appropriate to areas with different ground shaking characteristics. For example, "geologic hazard zoning" might be applied to areas of very thick saturated sediments with high (long) fundamental ground periods equivalent to that of buildings likely to be in that zone, for example, high-rise structures. Ordinances might require 


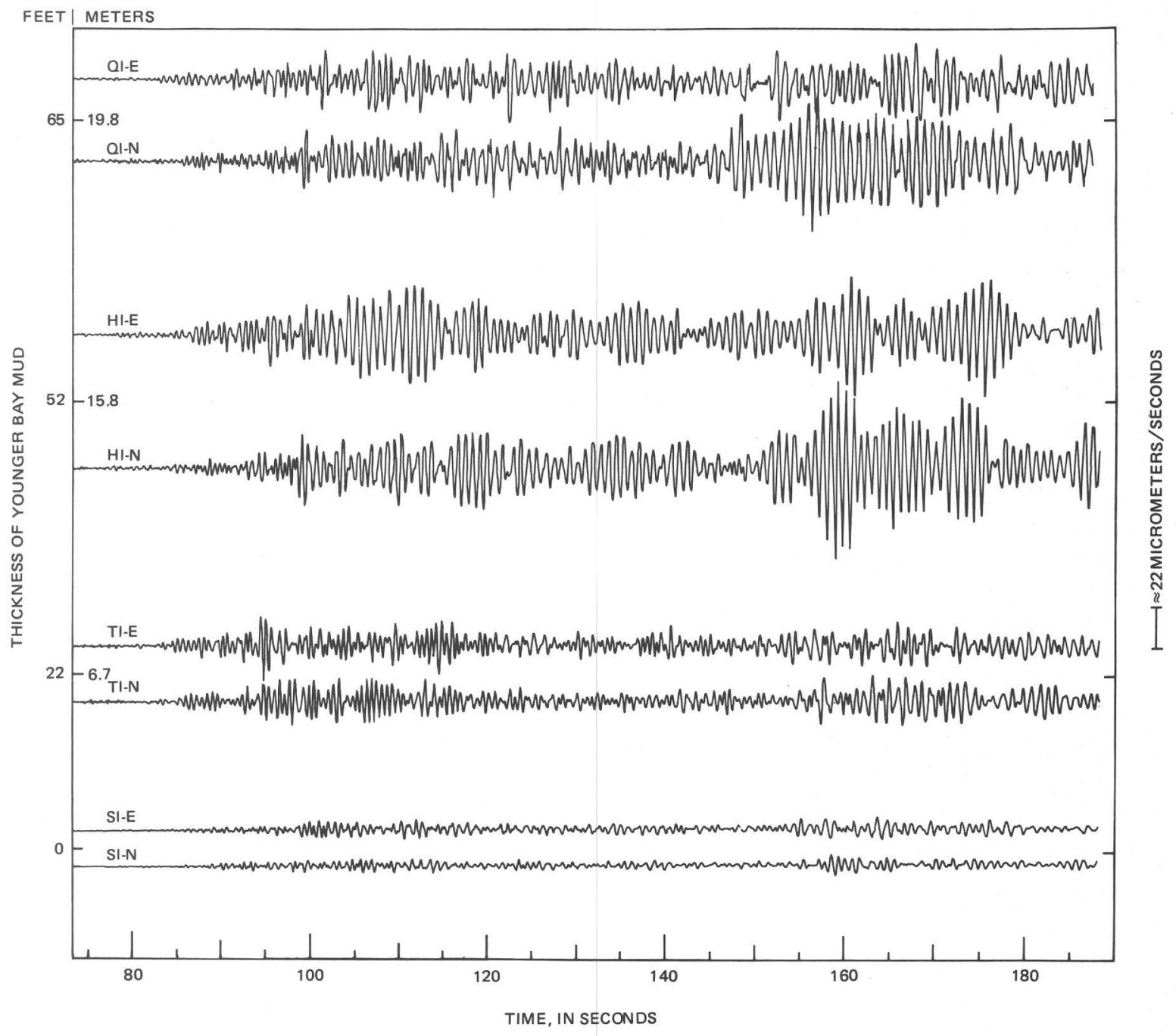

FIGURE 15.-Seismograph records from a single nuclear explosion show the differences in amplification of energy with increased thickness of bay mud. (From Borcherdt, 1970, fig. 5.)

that increasingly detailed geologic, soil engineering, and structural engineering analyses be performed for buildings with the highest projected occupancies in areas of greatest expected shaking motion. Because, as discussed earlier, it is difficult to predict strong ground motion (strong motion) characteristics and their effects quantitatively, it is desirable to establish a legal and procedural framework that remains flexible enough to accomodate increasingly sophisticated methods of prediction.

Other measures that are critical to a lessening of potential loss of life include the adoption and strict enforcement of a hazardous building abatement ordinance and an ordinance to require removal of dangerous parapets. Because of the potential economic impact, hazardous building abatement regulations might best be imposed gradually on a priority basis, selecting first those structures that are the most dangerous and with the highest occupancies, followed by buildings that constitute a lesser hazard and that have lower occupancies. Parapet ordinances, if enforced in urbanized areas, particularly where older high-rise structures may have poorly secured appendages (fig. 16), have the potential of sharply reducing casualties and property damage during major earthquakes.

\section{GROUND FAILURE}

Earth materials in a natural condition tend to reach equilibrium over a long period of time. In 


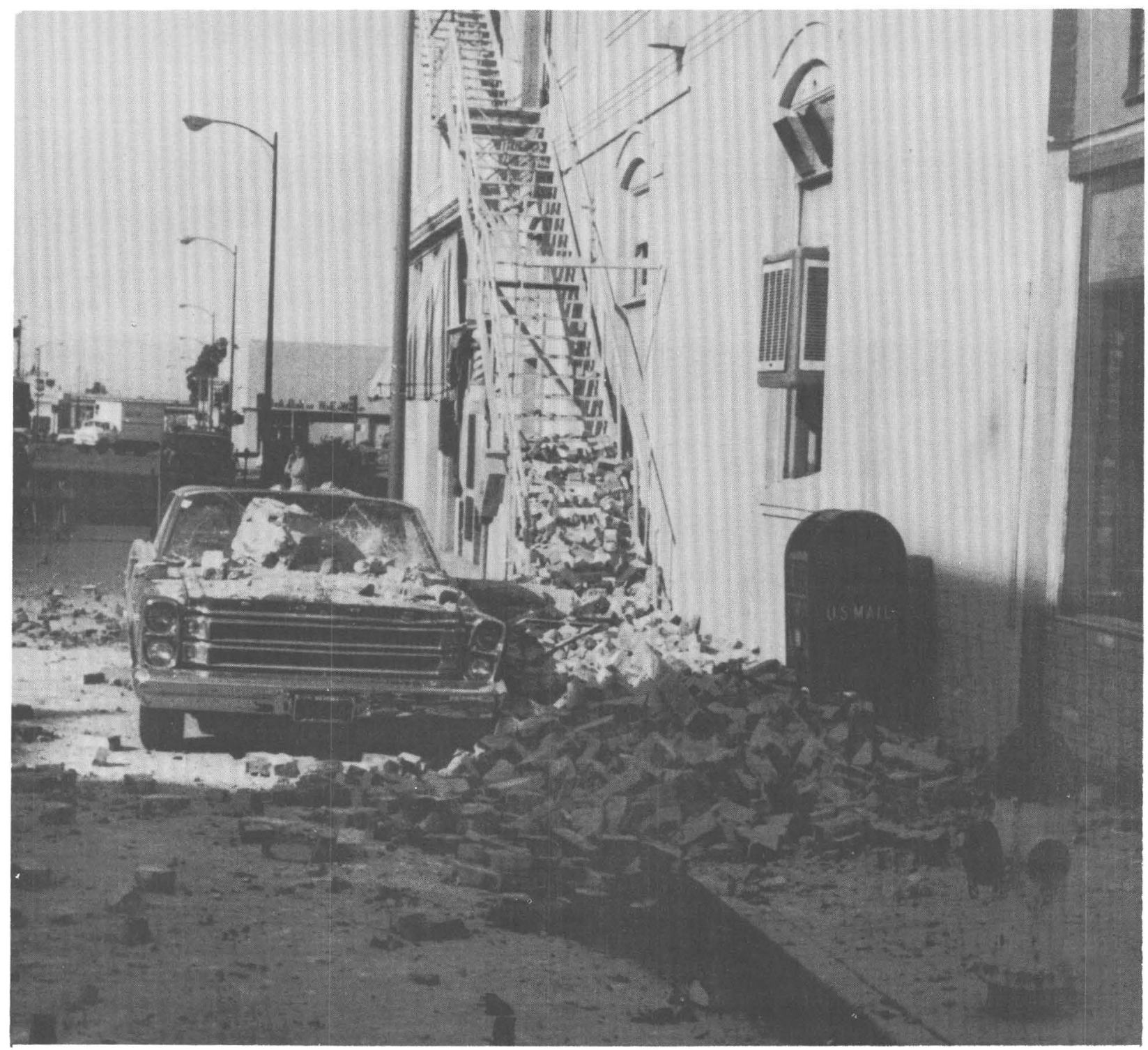

Figure 16.-Unreinforced parapets, which collapsed during the moderate (magnitude 5.7) 1969 Santa Rosa earthquake, caused severe damage to persons and property. (From Alquist, 1971, p. 20.)

geologically young and active areas such as California and Alaska, there are many regions where earth materials have not yet reached a natural state of stability. For example, most of the valleys and bay margins are underlain by recent loose materials that have not been compacted and hardened by long-term natural processes. Landslides are common on most of the hills and mountains as loose material moves downslope. In addition, many activities of man tend to make the earth materials less stable and hence to increase the chance of ground failure. Some of the natural causes of instability are earthquakes, weak materials, stream and coastal erosion, and heavy rainfall. Human activities that contribute to instability include oversteepening of slopes by undercutting them or overloading them with artificial fill, extensive irrigation, poor drainage or even ground-water withdrawal, and removal of stabilizing vegetation. These causes of failure, which normally produce landslides and differential settlement, are augmented during earthquakes by strong ground motions that result in rapid changes in the state of earth materials. It is these 
changes, by means of liquefaction and loss of strength in fine-grained materials, that result in so many landslides during earthquakes as well as differential settlement, subsidence, ground cracking, ground lurching, and a variety of transient and permanent changes in the ground surface.

\section{MECHANISMS OF FAILURE}

Liquefaction is a common mechanism causing many types of ground failure. It occurs when the strength of saturated, loose, granular materials (silt, sand, or gravel) is dramatically reduced, such as may occur during an earthquake. The earthquake-induced deformation transforms a stable granular material into a fluidlike state in which the solid particles are virtually in suspension, similar to quicksand (fig. 17). The result, where the liquefied materials are in a broad buried layer, may be likened to the action of ball bearings in reducing friction in the movement of one material past another. The Juvenile Hall landslide during the 1971 San Fernando earthquake resulted from liquefaction of a shallow sand layer and involved an area almost a mile long and a failure surface that had a slope of only $2 \frac{1 / 2}{2}$ percent (fig. 18 and Youd, 1971, p. 107, 108). Where the liquefied granular layer is thick and occurs at the surface, structures may gradually sink downward. The

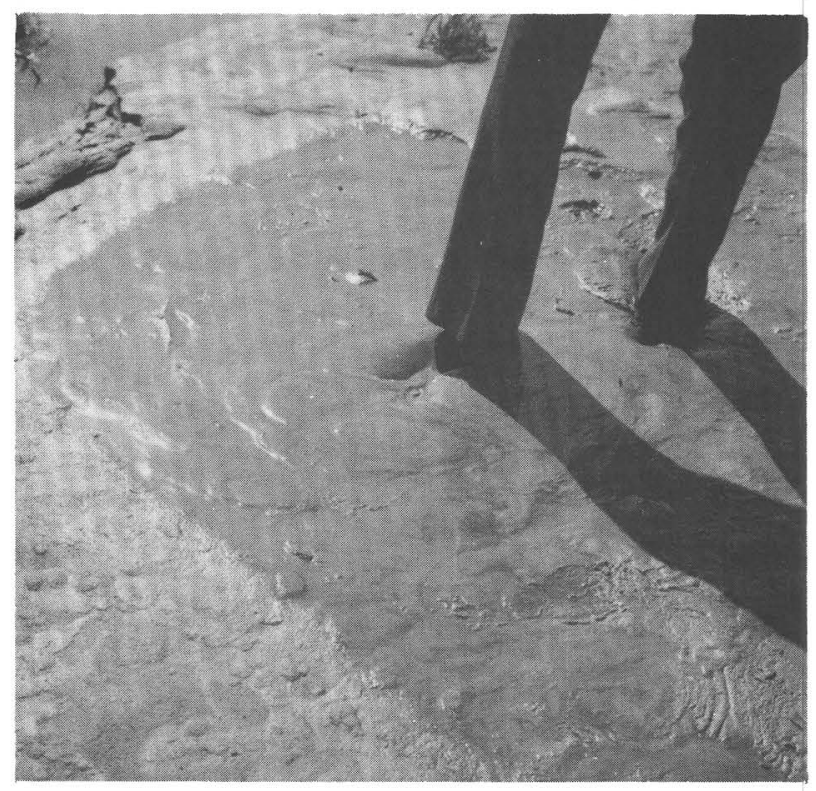

Figure 17. - Sand, liquefied during the 1973 Point Mugu earthquake, fails to support the man. Loose, saturated, granular materials commonly are stable until an earthquake sharply reduces their strength. tilting and sinking of buildings during the Niigata earthquake illustrate this phenomenon (fig. $19 \mathrm{~A}$, $B)$.

Loss of strength in fine-grained cohesive materials is another mechanism of ground or foundation failure and might manifest itself in squeezing or "lateral spreading" of soft, saturated clays (fig. 20) such as San Francisco Bay mud. It can result in rapid or gradual loss of strength in the foundation materials so that structures built upon them gradually settle or break up as foundation soils move laterally by flowage.

Other causes for loss of resistance include raising the ground water to reduce frictional resistance along a potential failure surface and removal of water or earth masses that may be serving as a buttress to prevent downslope movement.

\section{RESULTS OF GROUND FAILURE}

Although the basic causes of ground instability are simple in concept, the consequences are often complex and highly variable. They include numerous varieties of landslides, ground cracking, lurching, subsidence, and differential settlement. Moreover, these types of ground failure occur on a wide variety of ground conditions. Landslides, for example, do not require a steep slope on which to form, particularly during earthquakes. Many occur on slopes that are virtually flat, and the surface on which they fail may be very shallow (1 to 2 feet deep) or as much as hundreds of feet below the ground surface. The type of ground failure that develops in a given area is determined partly by the nature of the natural or manmade disturbance that occurs and partly by the topographic, geologic, hydrologic, and geotechnical characteristics of the ground.

Ground cracking usually occurs in stiff surface materials and is associated with changes in surface topography or materials. For example, during the 1964 Alaskan earthquake, much of the ground cracking that occurred along river flood plains adjacent and parallel to stream channels and along road and railroad embankments resulted from differential movement owing either to liquefaction or to lateral spreading of a relatively soft, deeper layer under a stiffer surface layer (fig. 21). Cracks may be only hairline or several feet wide and from a few feet to hundreds of feet long.

Ground lurching may be both a transitory and permanent phenomenon. During earthquakes, soft saturated ground may be thrown into undulat- 


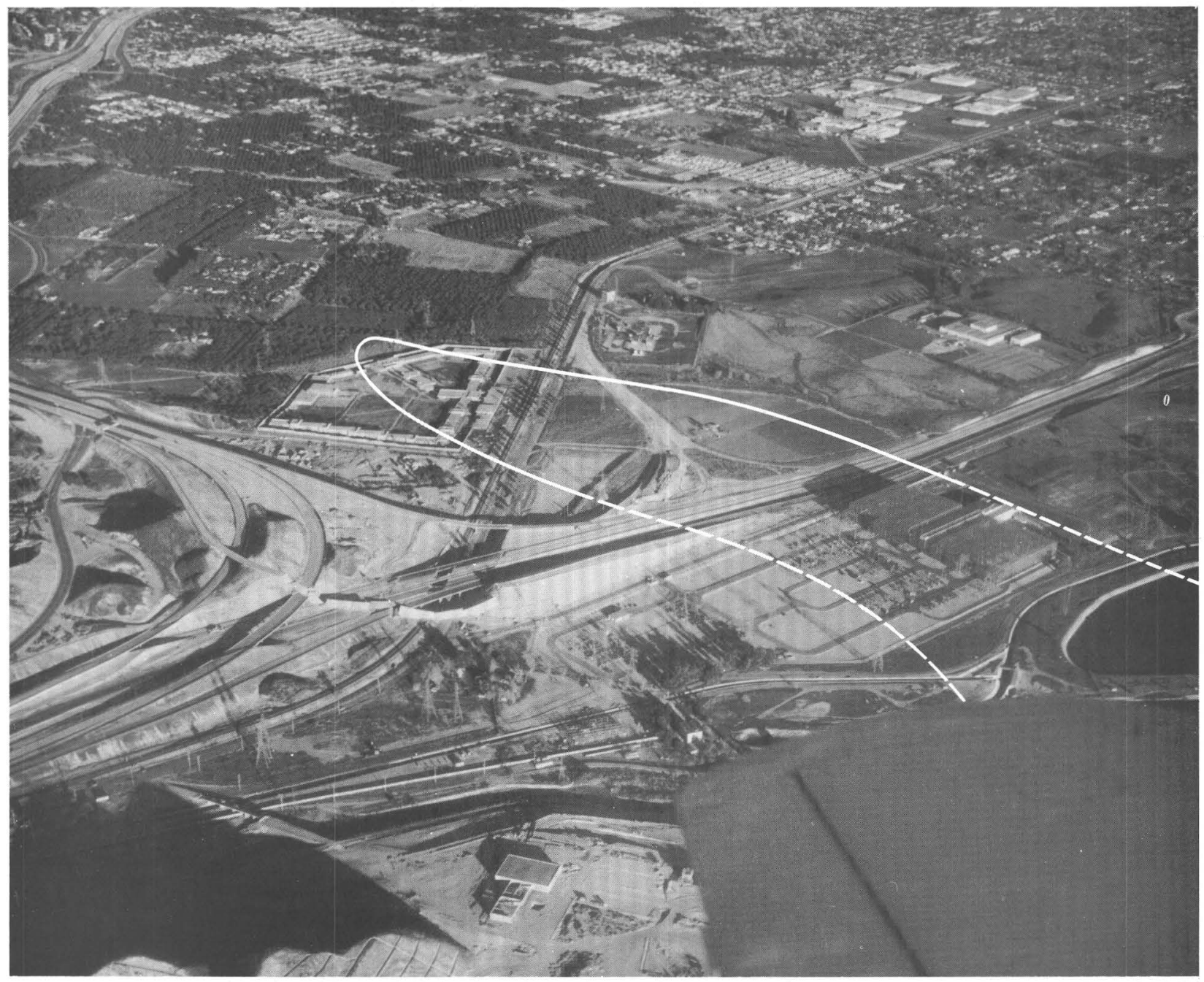

FIGURE 18.-The Juvenile Hall landslide (outlined), generated by the 1971 San Fernando earthquake, involved an area almost a mile long. It resulted from liquefaction of a shallow sand layer and has a failure surface with a slope of only $2 \frac{1}{2}$ percent.

ing waves that may or may not remain when the ground motion ceases (fig. 22). The same or similar ground surface appearance may also result from permanent differential settlement of the ground, which can be caused by loss of soil strength or by liquefaction. Commonly, the water freed by liquefaction of buried and confined granular layers is forced to the ground surface, moving laterally toward steep slopes or vertically along the planes of weakness in the overlying layers. As the water moves toward the surface or free face, it often carries with it some of the sand. Thus, sand boils, sand volcanoes (fig. 23), sand ridges (fig. 24), and similar anomalous features attest to the occurrence of liquefaction. As sand and water are removed from the subsurface, the ground settles, often differentially because the sand and water are seldom removed evenly over broad areas. The resulting effects on buildings can be catastrophic.

Subsidence of as much as several feet may occur over a broad area underlain by a thick sequence of sedimentary deposits. For example, after the 1906 earthquake, a well casing was reported to have "risen" 2 feet out of the ground, when, in fact, the ground around it probably liquefied or compacted as a result of the shaking. Subsidence is likely to be greatest in areas where there has been withdrawal of fluids (ground water or oil) over a long period of time. Lesser amounts of subsidence can occur even where fluid withdrawal has not taken place, as in the Homer area of Alaska in 1964. Compaction effects may be predicted with some 

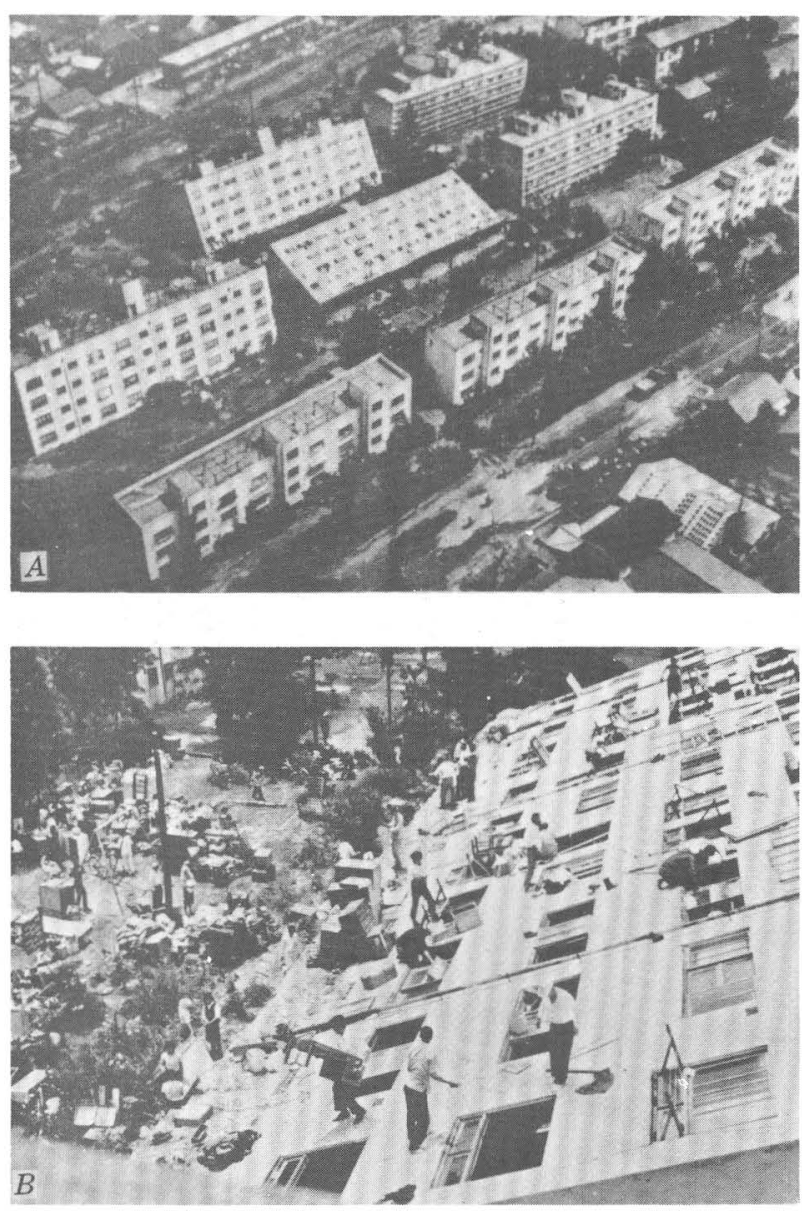

Figure 19.-Niigata earthquake phenomena. $A$, Tilting and sinking of buildings caused by reduction of foundation support due to liquefaction of near-surface sand deposits during the 1964 Niigata, Japan, earthquake. (From Kawasumi, 1968 , pl. 7.) $B$, Residents salvaging furniture and personal possessions by carrying them down the exterior walls of apartment building tilted by liquefaction. (From Kawasumi, 1968, pl. 7.)

degree of assurance over fairly broad areas (up to 1 or 2 miles) and even on a site basis, especially when the cause may be liquefaction.

\section{METHODS FOR ASSESSING GROUND FAILURE HAZARDS}

Basic data on ground failure should include maps and data on areas most subject to landslides, liquefaction, and ground lurching or cracking as outlined on pages 28-29. These are areas that, because of steep slopes, saturated granular subsurface deposits, or weak or unstable ground conditions, might fail during major earthquakes. One or more maps showing the areal distribution of

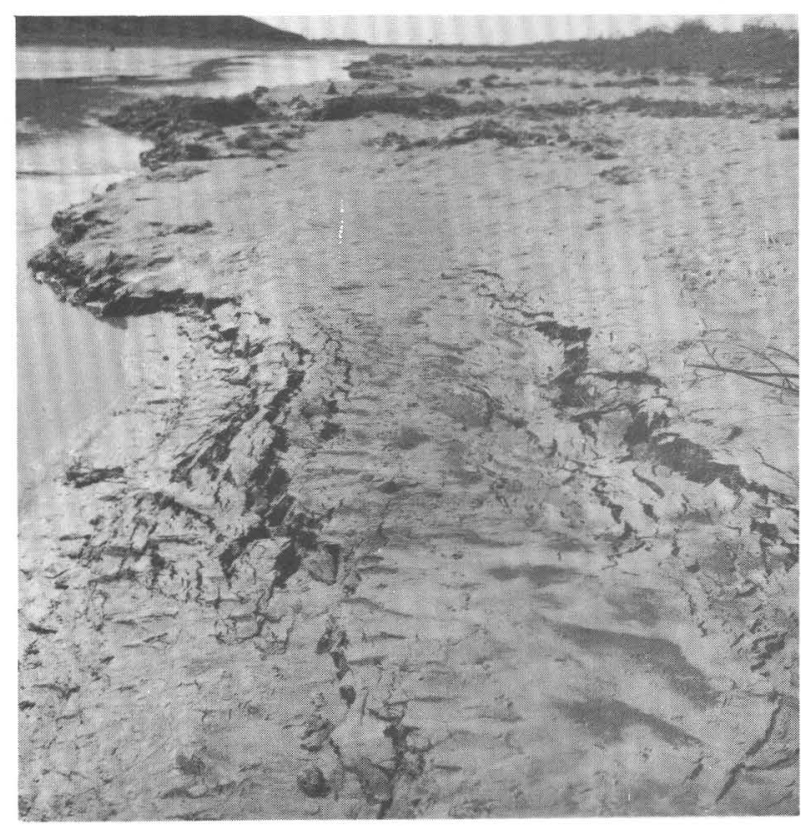

FIGURE 20.-Lateral spreading of soft, surficial materials toward an exposed slope occurred during the 1973 Point Mugu earthquake.

slopes and each of these ground conditions is desirable, although not always possible. An absolute predictive capability is virtually impossible except for specific sites after careful exploration and analysis.

\section{IMPLICATIONS FOR PLANNING AND LAND-USE CONTROLS}

General land-use policy might be guided partly by knowledge of broad areas where instability is believed to be so pervasive that, along with other considerations, its preservation as open space or other nonoccupancy, may be indicated (fig. 25). On the other hand, except during earthquakes, such failures generally occur fairly slowly, may be preceded by indicators, and usually do not result in loss of life, even though extensive or complete destruction of property is common. Therefore, the problem might be ignored. Alternatively, since ground failures can be life hazards during earthquakes, areas of known or likely low stability might be designated as geologic hazard zones. In such zones background studies (geologic and soil engineering reports) should be required to demonstrate that both static and dynamic hazardous conditions either do not exist or can be overcome by site preparation work or engineering design prior to approval of subdivision and site develop- 


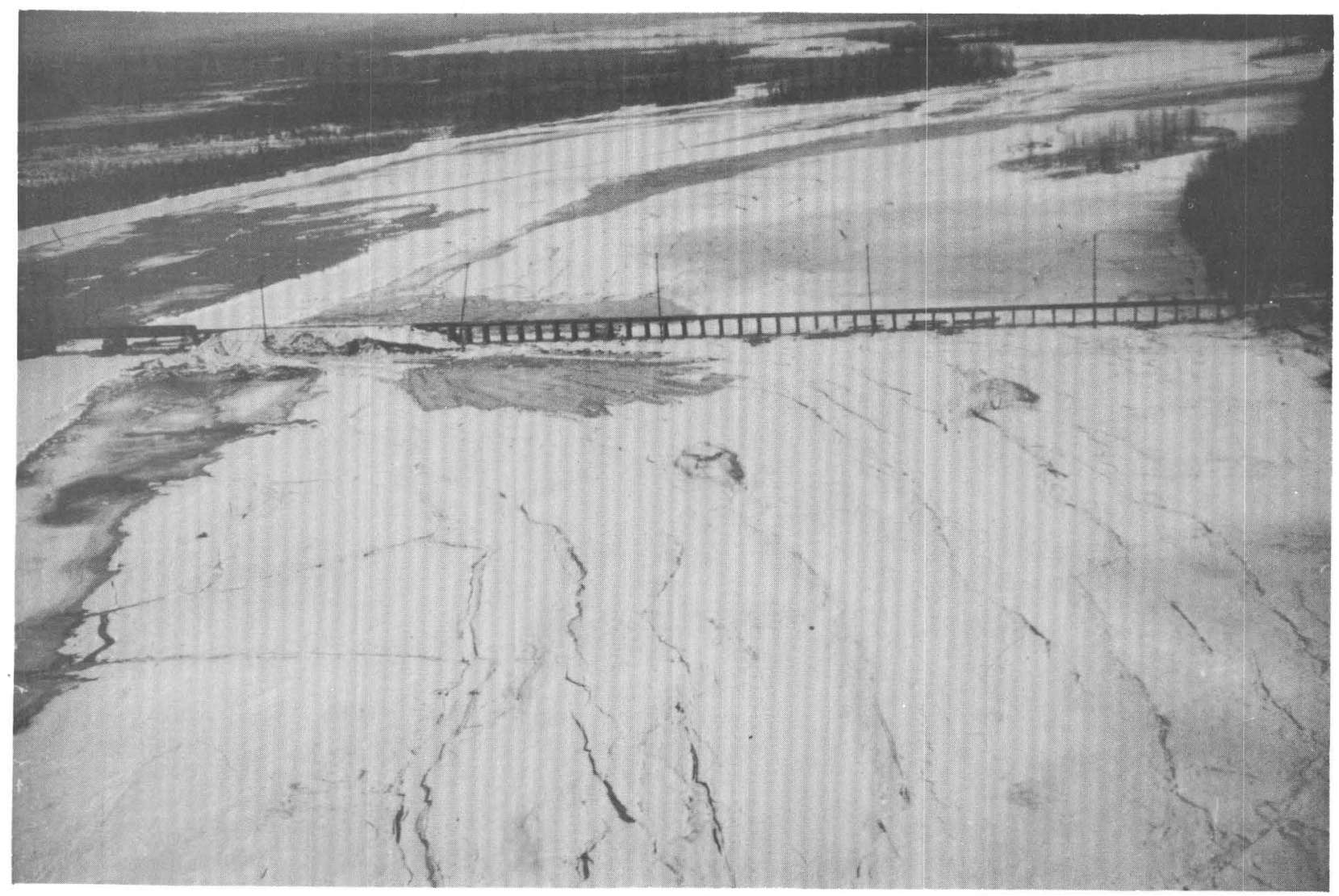

FIGURE 21.-Cracks in the active flood-plain sediments at the south end of bridge at Matanuska River, Alaska. An earthfill has been emplaced to substitute for a section of trestle damaged by shearing of wood piles at the ground.

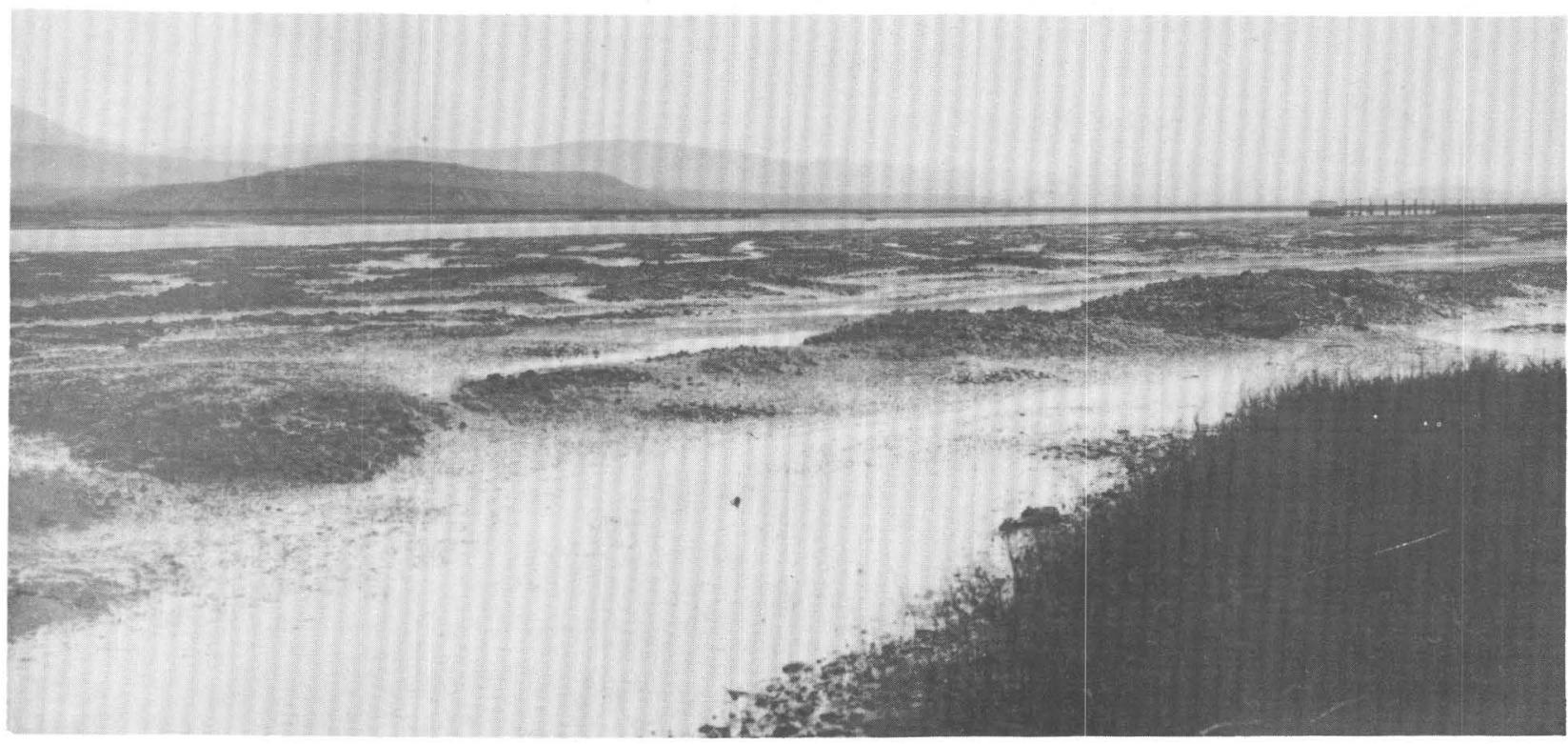

Figure 22.-Ground lurching on tidal flat at head of Tomales Bay, Calif., during the 1906 earthquake produced ridges and waves in tidal muds. 


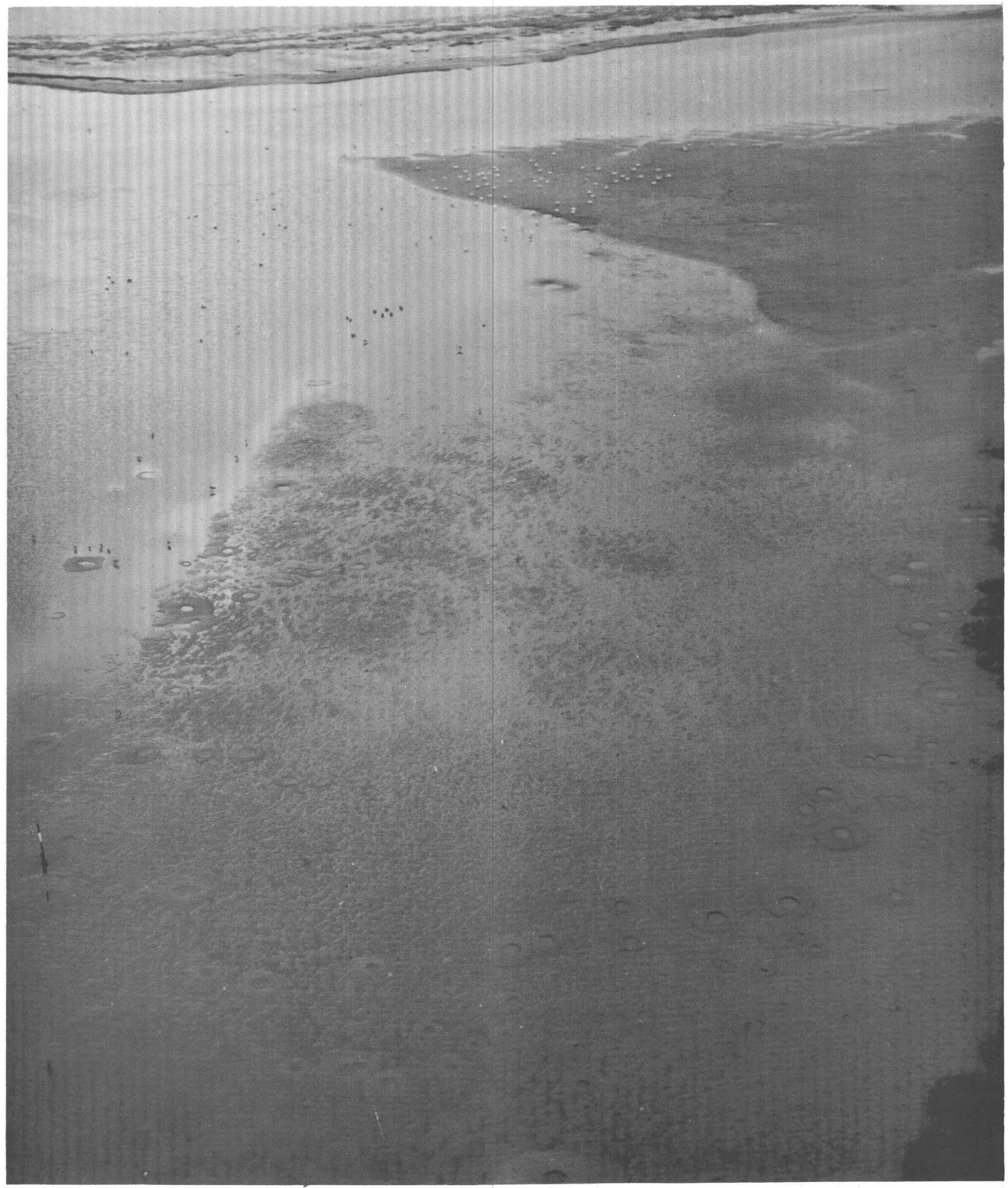

Figure 23.- Sand volcanoes in tidal flats produced by shaking of water-saturated sands during the 1973 Point Mugu earthquake. Using the birds for scale, the largest sand volcanoes are estimated to be several feet across. 


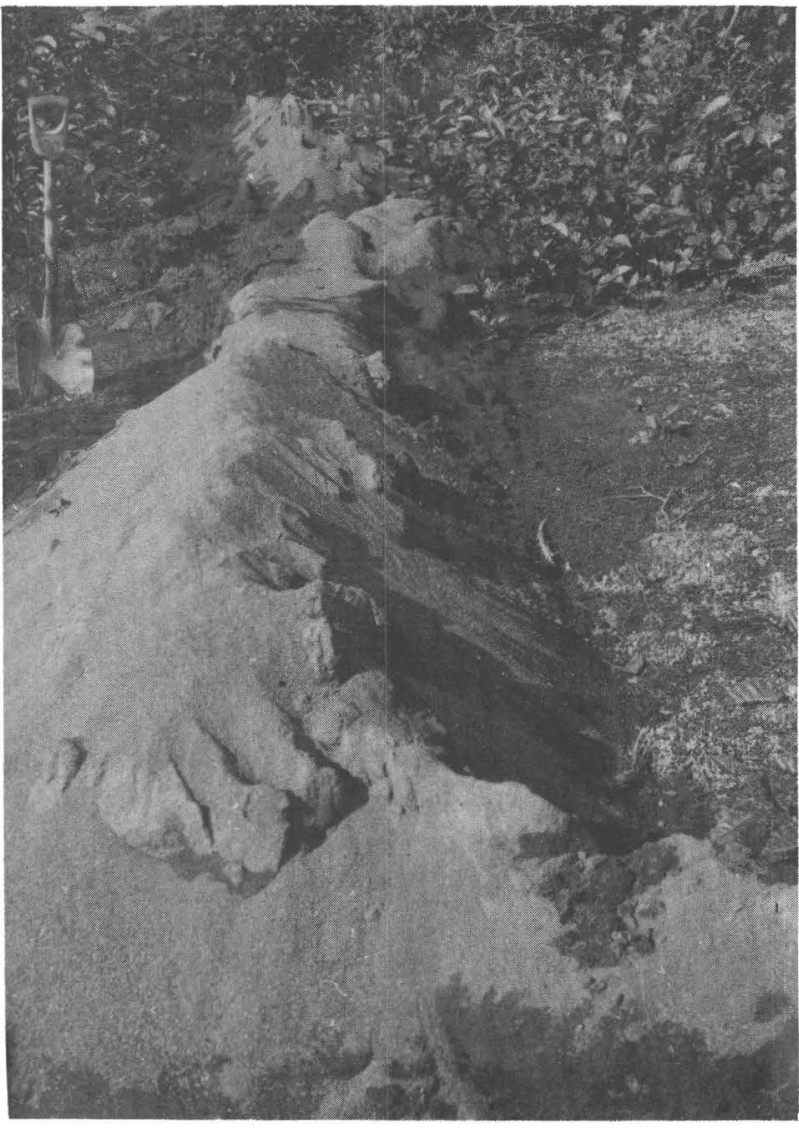

Figure 24.-Ridges, formed by fluid injection of sand in ground cracks are exposed following the 1964 Alaskan earthquake. Shovel provides scale.

ment applications. Although individual structures may be sited safely in such areas, roads, gas, water, and sewer lines can seldom be built without crossing unstable areas. Long-term costs in the form of public services may be great and generally must be borne by the entire community (table 1 ).

Other solutions to instability problems that are being pursued include adoption of a program to allow tax deductions for property owners whose land is particularly susceptible to ground failure. Such a program might be designed to alleviate tax burdens on property where existing structures are being damaged and on unimproved land as long as it remains unimproved or until the owner can demonstrate that he has eliminated the hazardous conditions. For those relatively few developed areas where severe instability problems are known to exist and disaster merely awaits the
TABLE 1.-Some economic costs resulting from development on unstable areas ${ }^{1}$

The economic loss as a consequence of development on these landslide deposits is already large, will continue to grow, and will probably become significantly greater if additional development is permitted without thorough engineering geology investigations of the area. The estimated 1969-70 loss in market value for all houses in San Jose Highlands, for example, was $\$ 228,000$, the loss for lots was $\$ 195,000$, and the loss in valuation for specific landslide damage to certain houses was $\$ 61,520$ the loss in valuation for specific landslide damage to certain houses was $\$ 61,520-a$ total loss of $\$ 484,520$ (Santa Clara County Assessor's Office, written commun., Sept. 22,1971 ). The cost data below, provided by the San Jose Department of Public Works
(written commun., Sept. 28,1971), reveal the variety and magnitude of expenses to a municipality when landslide activity takes place within a subdivision area.

Actions taken by and financed by the City of San Jose in the San Jose Highlands area, 1968-71

Soils study and consultant fees

Soils study and consultant fees

Consultant for new road

Construct 1,400 foot gravel-fill interception ditch

(no water was apparently removed).

Clean Hydraughers several times

Construct dewatering wells (deactivated after

1 year, no apparent help).

Above-ground flexible aluminum sanitary sewer.

Above-ground fiexible alum

Sewer photograph survey

Replace sanitary sew

Aerial photography

4,000 feet of new access around

4,000 feet of $n$
landslide area

Winter and spring road maintenance to remove ground swells and increasing grade due to downward creep

$\begin{array}{rr}1968 & \$ 10,000 \\ 1969 & 10,000 \\ 1970 & 30,000 \\ 1969 & 15,000 \\ & 3,000 \\ 1969 & 25,000 \\ & \\ 1968 & 4,500 \\ 1971 & 3,000 \\ 1971 & 7,000 \\ & 2,000 \\ & 550,000\end{array}$

\begin{tabular}{rr}
1967 & 0 \\
1968 & 9,000 \\
1969 & 30,000 \\
1970 & 32,000 \\
5 months of 1971 & 30,000 \\
\hline
\end{tabular}

Total

$\$ 760,500$

Estimated value of city streets in San Jose Highlands

(exclusive of new access road)
Estimated value of city utilities (street lights and sewers) $\$ 750,000$ $\$ 300,000$

Landslide damage to gas lines in San Jose Highlands totaled $\$ 20,000$ by late 1970 (Pacific Gas and Electric Co., written commun., Nov. 18, 1970). Landslide damage to (Pacific Gas and Electric Co., written commun., Nov. 18, 1970). Landslide damage to water lines has become progressively worse according to the following figures pro-
vided by the San Jose Highlands Water Company (written commun., Nov. 3, 1971):

$\begin{array}{ll}1967-68 & \text { (1 repair) } \\ 1968-69 & \text { (5 repairs) } \\ 1969-70 & \text { (20 repairs) } \\ 1970-71 & \text { (20 } 215\end{array}$

No information was obtained on the cost of landslide damage in the map area outside of the San Jose Highlands, but landslides were a substantial and presumably costly problem during and after construction of terminal facilities for the South Bay aqueduct (California Department of Water Resources, 1966).

${ }^{1}$ Taken from Nilsen and Brabb, 1972.

triggering action of an earthquake or an exceptionally wet winter, consideration should be given to the implementation of a hazardous building abatement ordinance or the initiation of nonconforming use procedures.

\section{TECTONIC DEFORMATION}

Earthquakes may produce major differential vertical and horizontal movements over broad parts of the earth's crust. For example, as a result of the 1964 Alaskan earthquake, between 70,000 and 110,000 square miles of both the sea floor and land in southern Alaska were warped, elevating or depressing them as much as 6 feet; elevation changes locally exceeded 50 feet (fig. 26 and Hansen and others, 1966, p. 17). While the effect of compaction and tectonic subsidence may appear 


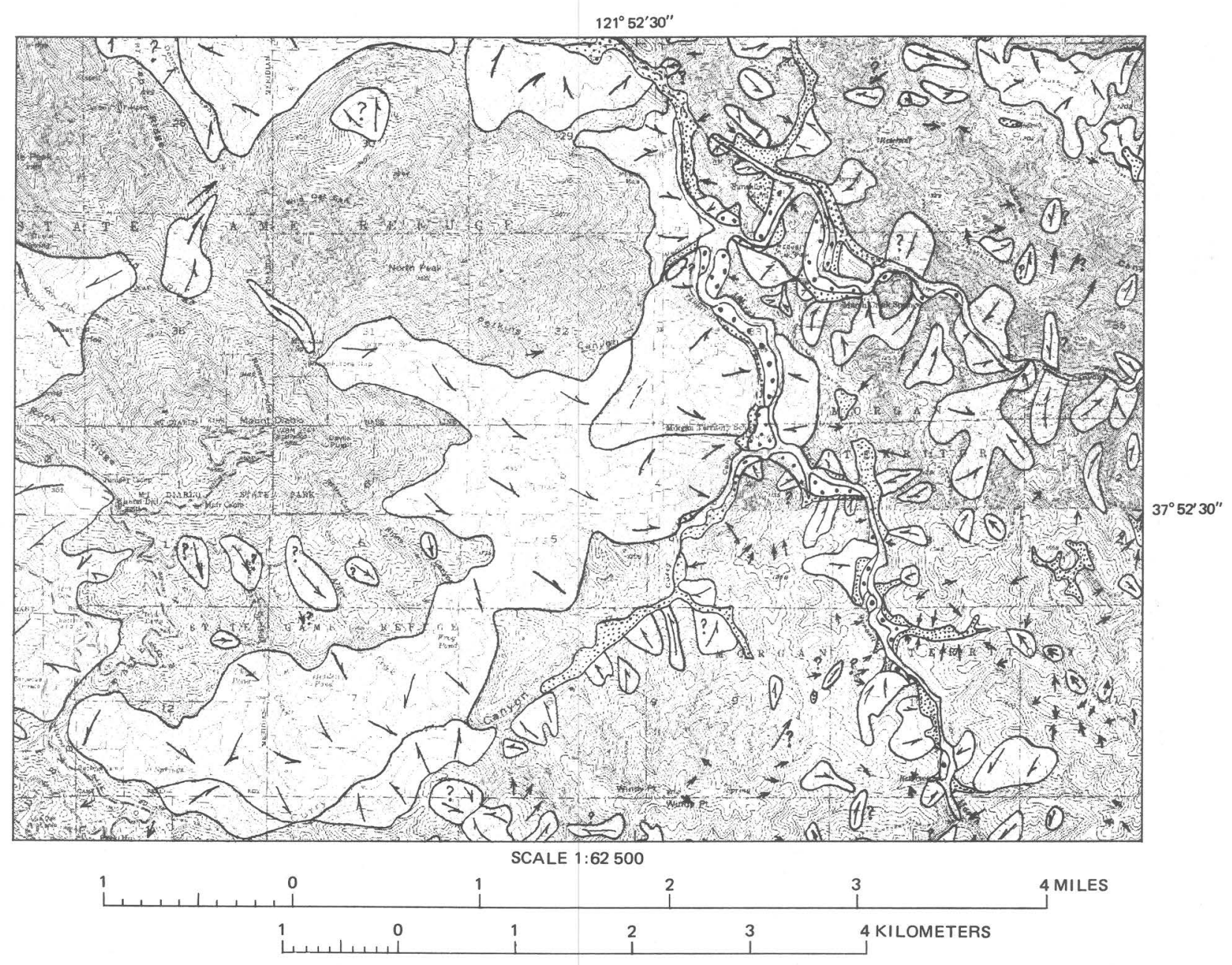

Figure 25.-Landslide distribution in Mount Diablo area, Contra Costa and Alameda Counties, Calif. Such maps, based largely on aerial photograph interpretation, are valuable in alerting public agencies to areas of known and possible low slope stability. Arrows show the direction of landslide movement. (From Nilsen, 1971.)

the same locally, the mechanisms differ greatly, and the total area affected will be much greater where the cause is tectonic deformation. Tectonic land changes result from major movements in the earth's crust, and neither their location nor their magnitude is predictable. Therefore, there is little that can be done to minimize the effects of these changes before they occur.

\section{TSUNAMI AND SEICHE EFFECTS}

Tsunamis are large ocean waves generated by rapid changes in elevation of large masses of earth and ocean. They are commonly caused by vertical faulting beneath the ocean that rapidly moves a large volume of earth and water. Such rapid movement may generate huge waves of destructive force that can travel thousands of miles. Dur- ing the 1964 Alaskan earthquake, for example, faulting and crustal warping created tsunamis, or sea waves, tens of feet high that spread more than 1,500 miles from the source area and caused devastation to many coastal communities within their reach (fig. 27). The effects of tsunamis can be greatly amplified by the configuration of the local shoreline and the sea bottom. Since a precise methodology does not exist to define these effects, it becomes important, through examination of the historic record, to determine if a particular section of the coastline has been subjected to tsunamis and to what elevation they have reached. It is also desirable to attempt to assess what amplifying effect a local coastal topographic configuration might have on uniquely directional incoming waves. 


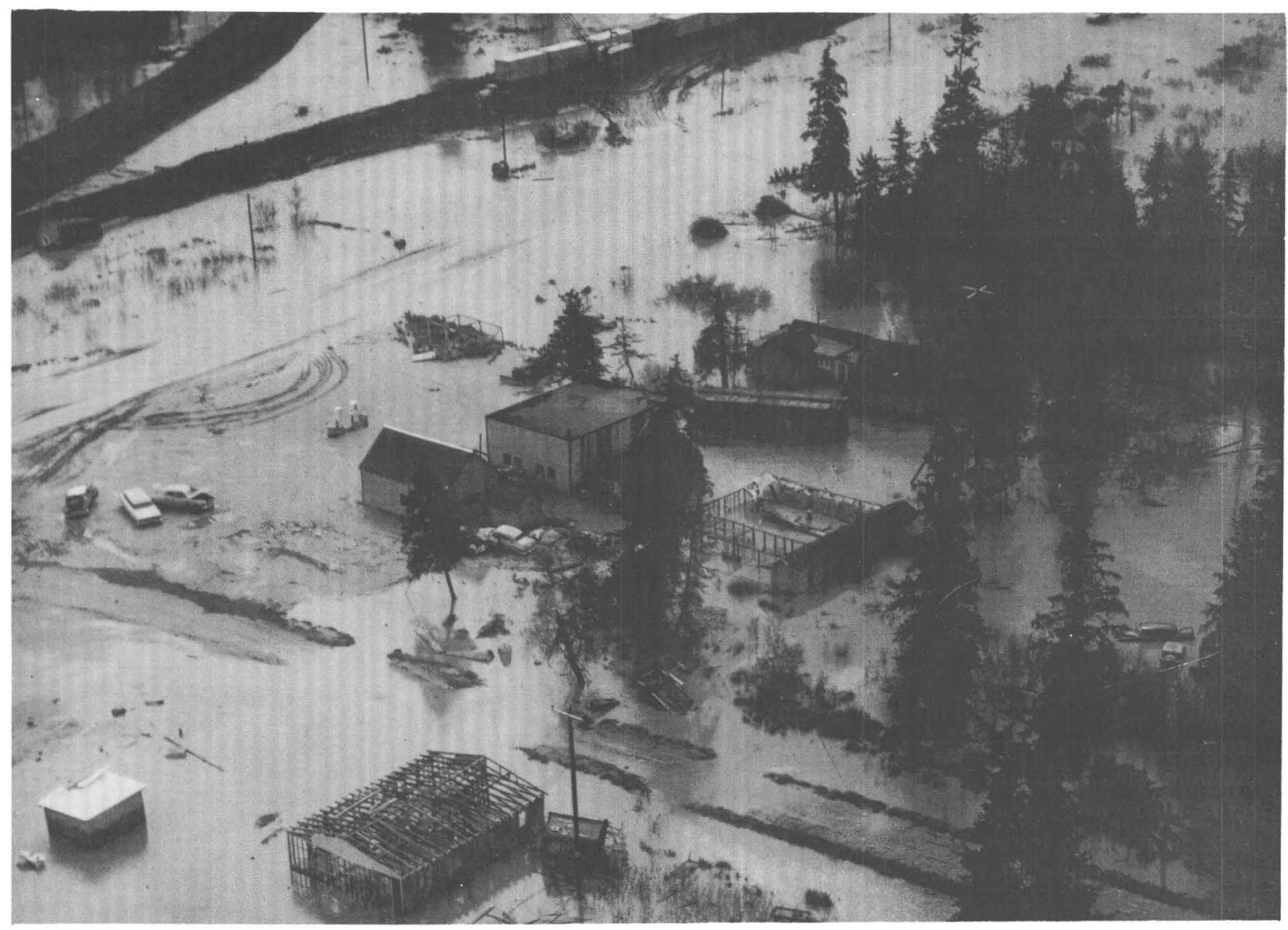

Figure 26.-Flooding of the Portage area of Alaska was caused by regional subsidence and by tectonic land changes from the 1964 earthquake.

Seismic seiches, or earthquake-generated standing waves, occur within enclosed or restricted bodies of water (lakes, reservoirs, bays, and rivers). They can be likened to the oscillations produced by the sloshing of water in a bowl or a bucket when it is shaken or jarred. Seiche waves generally have a low amplitude (less than a foot), but in shallow areas or where the water is constricted, wave runup can be as great as 20 or 30 feet (McCulloch, 1966). Obviously, such high runups can have a devastating effect on people and property within their reach; dams and reservoirs can be overtopped and large volumes of water released to inundate downstream development.

Large water waves causing catastrophic inundation can also result during an earthquake from a dam failure or from large-scale landsliding into a reservoir or bay. The near failure of the Van Norman reservoir during the 1971 San Fernando earthquake required the evacuation of 80,000 people that lived below it (Seed, 1972, p. 14). Although not the result of an earthquake, almost 3,000 lives were lost in Italy in 1963 when a huge landslide (more than 312 million cubic yards of material) suddenly fell into Vaiont Reservoir, sending up a wall of water and rocks 850 feet above reservoir level opposite the slide area and waves of water about 330 feet above the crest of the dam (fig. 28 and Kiersch, 1964). Waves were more than 230 feet high in the narrow valley as far as 1 mile downstream from the dam. Earthquake-generated landslides of this magnitude are possible hazards to dams or reservoirs. The 1958 Alaskan earthquake produced a massive rockfall that plunged into an inlet at the head of Lituya Bay, causing water to surge against the opposite wall of the inlet and to wash out trees up to 1,720 feet above sea level (fig. 29 and Miller, 1960, p. 51). It is extremely fortunate that the bay was uninhabited and that no more than two fishermen died when 


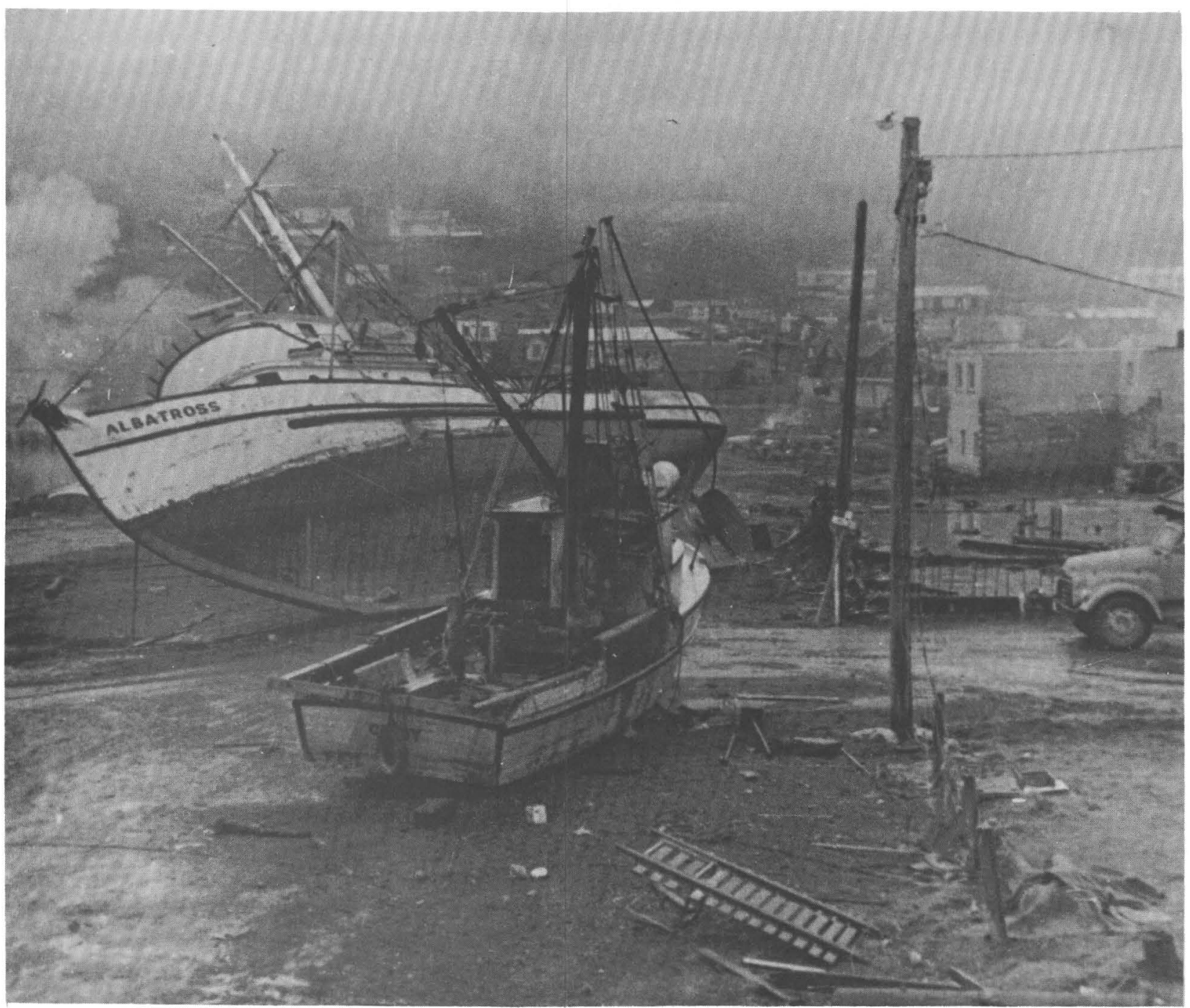

Figure 27.-Damage to shipping and structures at Kodiak from a tsunami generated by subsea faulting during the 1964 Alaskan earthquake.

their boat was destroyed as the wave passed out of the mouth of the bay.

\section{METHODS FOR ASSESSING WAVE AND FLOODING HAZARDS}

Assessing the hazards from tsunamis and seiches is very difficult and subject to varying interpretations because of very limited historical data and theoretical knowledge. Nevertheless, wave runup elevations could be predicted for most ocean and lake shorelines from examination of historic records. An attempt should be made to assess the amplifying effect of unique topographical coastal configurations even though the methodology may be very crude. Potential areas of catastrophic inundation from dam and reservoir failure or from landslide-generated waves that overtop dam crests, on the other hand, can be mapped for all large bodies of water perched above populated areas. Recently passed legislation in California now requires the dam owners to prepare maps showing areas of potential inundation for use in disaster and land-use planning.

\section{IMPLICATIONS FOR PLANNING AND LAND-USE CONTROLS}

Stringent controls should be applied to all land use within areas subject to tsunami and seiche runup and in potential areas of inundation downstream from water-retaining structures that lie within active fault zones and landslide-prone 


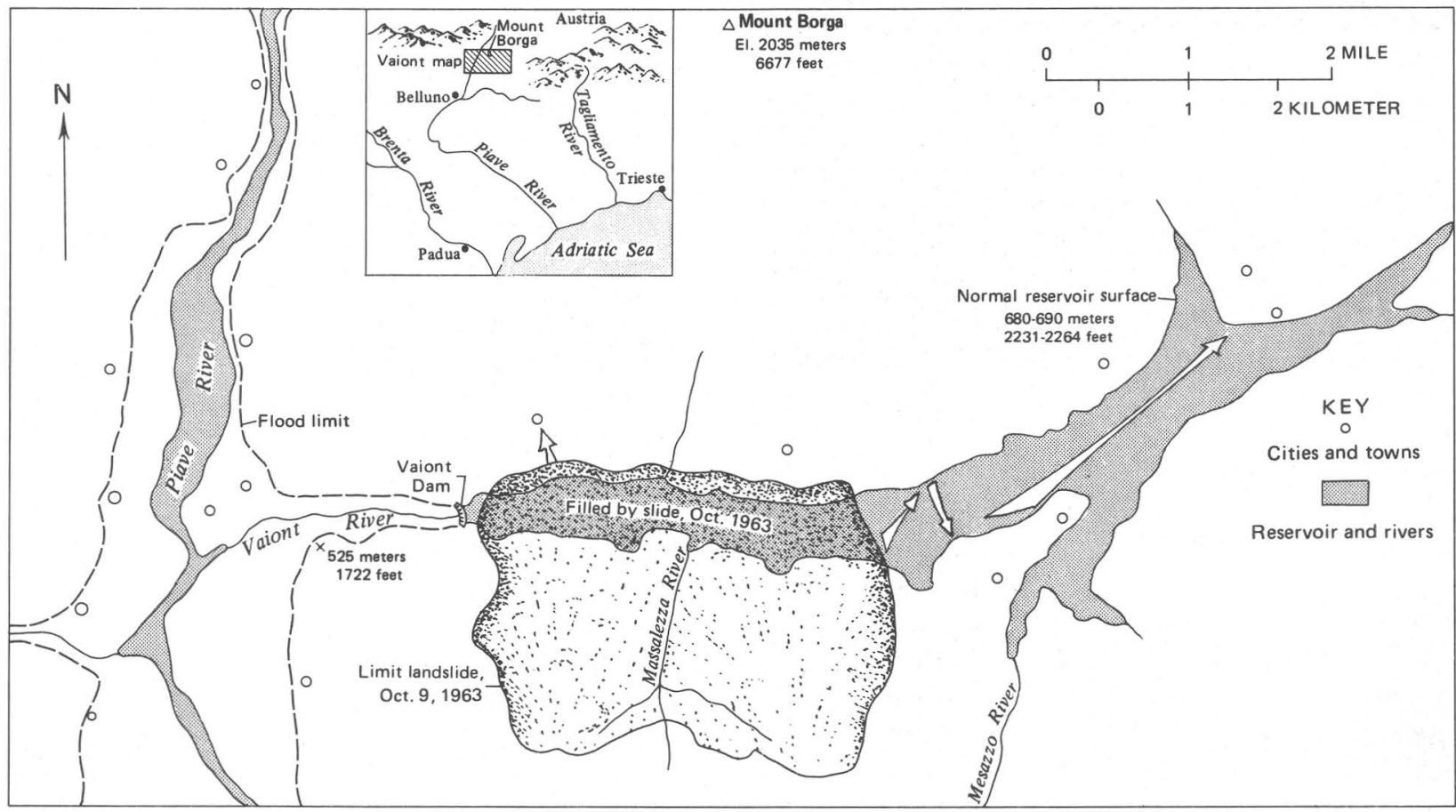

FIGURE 28.-Sketch map of Vaiont Reservoir showing the 1963 landslide which created waves that overtopped the dam and caused flooding and destruction over large areas downstream. (Modified from Kiersch,1964, fig. 1.)

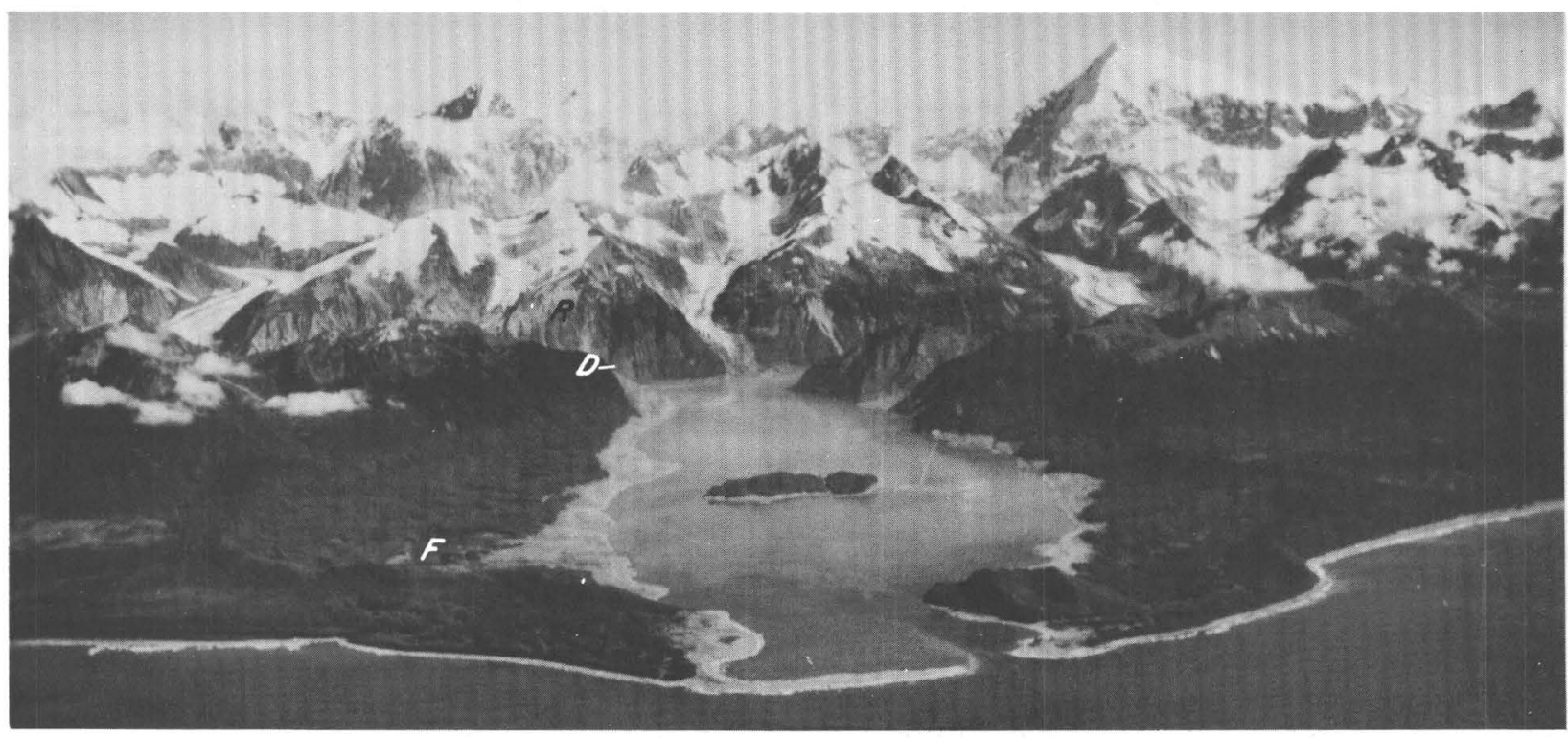

Figure 29.-A giant wave, generated at Lituya Bay, Alaska, on July 9, 1958 by a rockslide from the cliff (R) at the head of the bay, destroyed the forest over the light areas to a maximum altitude of 1,720 feet (D) and to a maximum distance of 3,600 feet inland from the high-tide shoreline at Fish Lake (F).

areas. These controls might include any of the following:

(1) Restrict land uses to those that are economically essential (for example, docks and warehouses) and warn owners, builders, and oc- cupants of the hazard. Prohibit siting of highoccupancy and critical structures (for example, schools, hospitals, police, and fire stations).

(2) Place areas of potential inundation under flood-plain zoning, prohibiting all new construc- 
tion and designating existıng occupancies as nonconforming.

(3) Where economically feasible and without encouraging a false sense of security, construct restraining or diversion structures to minimize potential inundation.

(4) Institute appropriate systems to warn of impending failure.

(5) Adopt and implement evacuation plans.

(6) Seek elimination of potentially hazardous dams or reservoirs.

\section{EARTH-SCIENCE DATA NEEDED TO ASSESS SEISMIC HAZARDS}

A rational formulation of land-use policies and of implementing regulations to minimize seismic hazards must rely on a broad base of earth-science information. Pertinent existing information, however, varies considerably from one locality to another. It should be recognized that the type, scope, and detail of geologic information needed will vary considerably in different areas depending on the complexity of the geology, the seismic history, type and distribution of existing and anticipated development, and the level of the planning effort. In a county where simple geologic relations and low seismic activity prevail, existing geologic mapping at a scale of 1:250,000 may be an adequate minimum informational level if the data are relatively recent and of high quality. In such instances compilation of existing information for analysis by planners in developing a comprehensive plan and its translation into model ordinances and land-use controls should require little additional data collection and should be relatively inexpensive. In areas of high seismicity and where complex geologic relations have not been resolved, however, an adequate comprehensive plan probably cannot be prepared without additional highly detailed (1:24,000 or larger scale) geologic, seismic, and engineering studies. Costs of these studies can vary considerably according to the amount of additional data needed, the number and type of disciplines involved, and the sophistication of interpretation provided. Consulting groups in the San Francisco Bay region in 1972-73 estimated costs for preparing seismic analyses as ranging between $\$ 2,000$ and $\$ 20,000$ for fairly simple geologic areas, where many data were available, or where the scope of interpretations was limited. In areas requiring much new detailed information, where the geology was complex, or where extensive, detailed analysis of the data was undertaken, these costs were estimated to range from $\$ 20,000$ to $\$ 100,000$ or more. These cost figures are offered as representative, and they may be exceeded under some circumstances.

Because detailed studies or complex analyses may take 2 years or more, interim policies based on a rapid geologic reconnaissance should guide development planning. These interim policies, since they would reflect unknown levels of risk, probably should be conservatively framed in areas of potential seismic hazard.

The type and scope of earth-science studies likely to yield the most valuable data include:

(1) Bibliographic research of geological and geophysical data, seismicity, historic earthquake records, including accounts of damage from shaking, faulting, and tsunamis. Such studies should include an evaluation of all existing published data.

(2) Interpretation of remote sensing data, including conventional aerial photographs. Both the earliest and most recent photography at different scales should be examined.

(3) Regional geologic maps, generally at a scale of 1:62,500 or larger. These commonly will have been prepared by the U.S. Geological Survey or state surveys.

(4) Special-purpose detailed geologic maps of fault traces and zones, landslides, unconsolidated deposits subject to liquefaction, settlement, and subsidence (figs. 2 and 25). These may have been prepared only by private consultants for individual sites although the federal and state surveys have been preparing such maps for large areas in recent years.

(5) Repeated geodetic measurements extending over long periods (decades) to detect possible horizontal and vertical land or sea changes. These are normally conducted only by public agencies to establish mapping control and design of facilities.

(6) Geophysical surveying to determine such things as depth to bedrock, seismic velocities, earth structure, magnetic properties of rocks, or shear wave properties. Surveying may have been conducted for research or design of specific facilities.

(7) Measurements of fault creep and earth strain. Normally undertaken for research.

(8) Seismometer arrays to determine seismic activity, fault location, type, and attitude, and likely hypocenter zones (fig. 9); conducted for research. 
(9) Strong-motion instrumentation data from different geologic environs and representative buildings, collected for design and research.

(10) Trenches across critical faults to determine location and type of displacement and to secure samples that might permit age dating of past movement to determine frequency of fault displacement. Trenches dug and examined both for research and site exploration.

(11) Subsurface exploration to locate water levels and barriers and to obtain samples for determination of soil properties needed in computing ground response characteristics. Such data are largely collected by consultants as part of site exploration studies.

(12) Detailed topographic maps and submarine profiles are needed to estimate slope stability, prepare possible inundation maps, and evaluate tsunami runup potential. Where available, these normally have been prepared by federal agencies but are being made increasingly for design of large coastal installations.

(13) Empirical or theoretical modeling of ground response in typical geologic/soil environments. Such work has been done in universities, by consultants, and by government researchers in the United States and some other countries.

(14) Preparation of relative risk maps. These have largely been prepared for specific, large land development projects.

Although the above list encompasses the general range of studies needed for a comprehensive analysis of seismic hazards, it is not necessarily complete; in many areas, many of the data already may be available.

\section{PRINCIPAL SOURCES OF GEOLOGIC AND SEISMIC DATA}

Sources of information on geologic and seismic data that may be available for a given area include the following:

(1) County or city departments of Building and Safety, Public Works, Building Inspectors, or Engineer's Office, especially if they contain a geologic staff, are a prime source of information. Although these offices are normally concerned with day-to-day problems of public works projects or in reviewing development and subdivision reports, they will probably have already compiled many available data, can evaluate their adequacy, identify significant gaps in data, and recommend the best means of obtaining additional data.
(2) Geology departments of local colleges and universities are likely to be a good source for information on the local geology and seismology. For example, in California the Seismological Laboratory at the University of California at Berkeley and at the California Institute of Technology at Pasadena operate seismograph stations in various parts of the state and undertake extensive seismological research. They can provide invaluable data in some areas. Student theses often discuss areas near the school, and both faculty members and graduate students may undertake consulting work nearby. The staff of the department might be willing to reference primary data sources and to make a preliminary judgment on adequacy. In any event, they should be able to direct the inquirer to other sources for help.

(3) Most states have a geological survey that may have a geologic mapping program underway and would be an excellent source for existing geologic data, or would be able to suggest the best method of obtaining additional data. In some instances, state surveys have entered into contracts with local governments to provide geologic maps and some interpretive maps. A few state surveys are developing a capability to conduct geophysical surveys and seismic studies and may undertake ground-response analyses.

(4) The U.S. Geological Survey has a nationwide program of geologic, hydrologic, and topographic mapping. Geologic and seismic research particularly applicable to an assessment of seismic hazards is concentrated largely in the San Francisco and Los Angeles areas and along the San Andreas and other major active faults in California and other western states. The U.S. Geological Survey is an excellent source for existing topographic, geologic, hydrologic, geophysical, and seismic data. Sources of additional data and possibly methods of interpretation and use may be suggested upon inquiry.

Many of the functions that were formerly undertaken by the National Oceanic and Atmospheric Administration (NOAA) are now being carried out by the U.S. Geological Survey - a nationwide strong-motion instrument program, measurement of fault creep and crustal strain, operation of a worldwide seismograph network, and maintenance of an earthquake information center in Boulder, Colo. Two other critical activities - operation of a tsunami warning system and geodetic 
surveying throughout the United States - continue to be conducted by NOAA.

(5) The U.S. Army Corps of Engineers and U.S. Bureau of Reclamation conduct geologic studies of dams, reservoirs, and related areas. In addition, the Corps of Engineers conducts various studies of drainage basins, harbors, and coastal areas. Some of these studies may yield data useful in assessing seismic hazards.

(6) Private consulting geologists and soil engineers are valuable, both as sources for existing data and as qualified consultants for the collection of new data and its analysis for seismic hazards. Their files often contain much relevant information (though generally not publicly available) obtained through work on a variety of construction projects - school and other public structures, streets and highways, utilities, and private developments.

(7) In many states one or more agencies have regulatory functions to require minimum standards of safety for major public structures including damage from earthquakes. These agencies commonly collect many valuable data or fund research projects. For example, in California, the Division of Safety of Dams in the Department of Water Resources has responsibility for approving the location and design and for the periodic inspection of all nonfederal dams more than 25 feet high or that can impound 50 acre-feet or more. The Office of Emergency Services, after consultation with the Department of Water Resources, is charged under a new state law to designate dams that require their owners to prepare maps of areas downstream that might be flooded upon failure of the dam. In addition, the geologic staff of the Department of Water Resources has conducted geologic and seismologic investigations along the route of most of California's major water projects.

(8) Professional organizations, such as the Association of Engineering Geologists, the Earthquake Engineering Research Institute, and others also may be very helpful. They commonly organize symposia (Nichols and Campbell, 1971), publish informative booklets addressed to both the professional and planners (Grading Codes Advisory Board and Building Code Committee, 1973), and maintain lists of consultants.

Small jurisdictions with few seismic hazards and without direct access to a staff of planners, geologists, and soil and structural engineers may find it necessary to contract for an evaluation of seismic risk. But, whatever the size of the jurisdiction, agency, or developer, such an evaluation, if comprehensive and thoughtful, will probably be the product of a multidisciplinary team effort, whether prepared solely by consultants, by jurisdiction staff, or by a combination of both.

\section{GLOSSARY}

Amplification. The increase in earthquake ground motion that may occur to the principal components of seismic waves as they enter and pass through different earth materials.

Bore hole. A hole drilled into the earth for exploratory purposes.

Damping. A resistance to vibration that causes a progressive reduction of motion with time or distance.

Epicenter. That point on the earth's surface directly above the point of origin of an earthquake.

Free face. A sloping surface exposed to air or water such that there is little or no resistance to lateral movement of earth materials.

Fundamental period. The longest period.(duration in time of one full cycle of oscillatory motion) for which a structure or soil column shows a response peak - commonly the period of maximum response.

Geodetic measurements. Controls on location (vertical or horizontal) of positions on the earth's surface of a high order of accuracy, usually extended over large areas for surveying and mapping operations.

Geophysical surveys. The use of one or more techniques of physical measurement to explore earth properties and processes.

Hazardous building. Building considered unsafe owing to poor design, poor construction techniques or materials, defects in foundation conditions, or damage from any one of several possible causes.

Hypocenter. That point along a fault within the earth where rupture begins and from which earthquake waves originate.

Intensity. A subjective measure of the force of an earthquake at a particular place as determined by its effects on persons, structures, and earth materials. The principal scale used in the United States today is the Modified Mercalli, 1956 version as defined below (modified from Richter, 1958, p. 137-138):

I. Not felt. 
II. Felt by persons at rest, on upper floors, or favorably placed.

III. Felt indoors. Hanging objects swing. Vibration like passing of light trucks. Duration estimated. May not be recognized as an earthquake.

IV. Hanging objects swing. Vibration like passing of heavy trucks; or sensation of a jolt like a heavy ball striking the walls. Standing automobiles rock. Windows, dishes, doors rattle. Wooden walls and frame may creak.

V. Felt outdoors; direction estimated. Sleepers wakened. Liquids disturbed, some spilled. Small unstable objects displaced or upset. Doors swing. Shutters, pictures move. Pendulum clocks stop, start, change rate.

VI. Felt by all. Many frightened and run outdoors. Persons walk unsteadily. Windows, dishes, glassware broken. Knickknacks, books, etc., off shelves. Pictures off walls. Furniture moved or overturned. Weak plaster and masonry $\mathrm{D}^{1}$ cracked.

VII. Difficult to stand. Noticed by drivers of automobiles. Hanging objects quiver. Furniture broken. Weak chimneys broken at roof line. Damage to masonry $\mathrm{D}$, including cracks; fall of plaster, loose bricks, stones, tiles, and unbraced parapets. Small slides and caving in along sand or gravel banks. Large bells ring.

VIII. Steering of automobiles affected. Damage to masonry C; partial collapse. Some damage to masonry B; none to masonry A. Fall of stucco and some masonry walls. Twisting, fall of chimneys, factory stacks, monuments, towers, elevated tanks. Frame houses moved on foundations if not bolted down; loose panel walls thrown out. Decayed piling broken off. Branches broken from trees. Changes in flow or temperature of springs and wells. Cracks in wet ground and on steep slopes.

IX. General panic. Masonry D destroyed; masonry $\mathrm{C}$ heavily damaged, sometimes with complete collapse; masonry B seriously damaged. General damage to foundations. Frame structures, if not bolted, shifted off foundations. Frames racked. Serious damage to reservoirs. Underground

'See Uniform Building Code for specifications on quality of masonry construction pipes broken. Conspicuous cracks in ground and liquefaction.

$X$. Most masonry and frame structures destroyed with their foundations. Some wellbuilt wooden structures and bridges destroyed. Serious damage to dams, dikes, embankments. Large landslides. Water thrown on banks of canals, rivers, lakes, etc. Sand and mud shifted horizontally on beaches and flat land. Rails bent slightly.

XI. Rails bent greatly. Underground pipelines completely out of service.

XII. Damage nearly total. Large rock masses displaced. Lines of sight and level distorted. Objects thrown in the air.

Left-lateral movement. A generally horizontal movement in which the block across the fault from the observer has moved to the left.

Magnitude. The rating of a given earthquake is defined as the logarithm of the maximum amplitude on a seismogram written by an instrument of specified standard type calculated to be at a distance of 62 miles $(100 \mathrm{~km})$ from the epicenter. The zero of the scale is fixed arbitrarily. The scale is open ended but the largest known earthquake magnitudes are near $83 / 4$. Because the scale is logarithmic, every upward step of 1 magnitude unit increases the recorded amplitude by 10 . (After Richter, 1958, p. 17).

Microearthquake. An earthquake having a magnitude of 2 or less on the Richter scale.

Microseismic event. Earthquake or maninduced vibrations observable only with instruments.

Modified Mercalli. See Intensity.

Normal fault. A vertical to steeply inclined fault along which the block above the fault has moved downward relative to the block below.

Plastic deformation. A permanent change, excluding rupture, in the shape of a solid.

Remote sensing. The acquisition of information or measurement of some property of an object by a recording device that is not in physical or intimate contact with the object under study. The technique employs such devices as the camera, lasers, infrared and ultraviolet detectors, microwave and radio frequency receivers, and radar systems.

Reverse fault. A steeply to slightly inclined fault in which the block above the fault has moved relatively upward or over the block below the fault. 
Right-lateral movement. Generally horizontal movement in which the block across the fault from an observer has moved to the right.

Right-normal fault. Horizontal movement in a right-lateral sense with accompanying normal fault movement. (See Right-lateral movement and Normal fault.)

Sag pond. Enclosed depression, generally occupied by water, formed when movement along a fault has disturbed the surface or subsurface continuity of drainage.

Sand boils. Turbid upward flow of water and some sand to the ground surface resulting from increased ground water pressures when saturated cohesionless materials are compacted by earthquake ground vibrations.

Sand ridges. Low ridges of sand extruded along fissures caused by ground cracking and expulsion of water and sand by liquefaction.

Sand volcano. A low, cone-shaped accumulation of sand produced by the upward expulsion of sand-laden water from compaction of saturated cohesionless materials subjected to earthquake ground vibrations.

Scarp. A cliff or steep slope formed by a fault, generally by one side moving up relative to the other.

Seismic. Pertaining to an earthquake or earth vibration, including those that are artifically induced.

Seismograph. An instrument that scribes a permanent continuous record of earth vibrations.

Seismometer. A device that detects vibrations of the earth, and whose physical constants are known sufficiently for calibration to permit calculation of actual ground motion from the seismograph.

Shear. A mode of failure whereby two adjacent parts of a solid slide past one another parallel to the plane of failure.

Shear wave. A distortional, secondary or transverse wave.

Strain. The amount of any change in dimensions or shape of a body when subjected to deformation.

Stress. In a solid, the force per unit area, acting on any designated plane within it.

Strike-slip fault. Fault in which movement is principally horizontal. (See Right-lateral movement and Left-lateral movement.)

Strong motion. Ground motion produced by a "strong" earthquake or one capable of producing damage to structures. The magnitude of such an earthquake may vary considerably according to the character of the earthquake.

Thrust fault. See Reverse fault.

\section{REFERENGES CITED}

Albee, A. L., and Smith, J. L., 1967, Geologic criteria for nuclear power plant location: Soc. Mining Engineers Trans., v. 238 , no. 4 , p. $430-434$.

Alquist, A. E., 1971, Seismic hazards-A question of public policy, in Nichols, D. R., and Campbell, C. C., eds., Environmental planning and geology: U.S. Geol. Survey and U.S. Dept. Housing and Urban Development, p. 16-21.

Atomic Energy Commission, 1971, Nuclear power plants, seismic and geologic siting criteria: Federal Register, v. 36 , no. 228, p. 22601-22605.

Barosh, P. J., 1969, Use of seismic intensity data to predict the effects of earthquakes and underground nuclear explosions in various geologic settings: U.S. Geol. Survey Bull. $1279,93 \mathrm{p}$.

Bonilla, M. G., 1970, Surface faulting and related effects, chap. 3 in Wiegel, R. L., ed., Earthquake engineering: Englewood Cliffs, N. J., Prentice-Hall, p. 47-74.

Bonilla, M. G., and Buchanan, J. M., 1970, Interim report on world-wide historic surface faulting: U.S. Geol. Survey open-file report, $32 \mathrm{p}$.

Borcherdt, R. D., 1970, Effects of local geology on ground motion near San Francisco Bay: Seismol. Soc. America Bull., v. 60 , no. 1 , p. $29-61$.

Borcherdt, R. D., Joyner, W. B., Nichols, D. R., Chen, A. T., Warrick, R. E., and Gibbs, James, 1972, Ground motion predictions, in Microzonation Conference: Internat. Conf. on Microzonation for Safer Construction Research and Application, Seattle, Wash., Oct. 30-Nov. 3, 1972, Proc.,v. II, p. 862.

Brown, R. D., Jr., and Wallace, R. E., 1968, Current and historic fault movement along the San Andreas fault between Paicines and Camp Dix, California, in Dickinson, W. R., and Grantz, Arthur, eds., Proceedings of conference on geologic problems of San Andreas fault system: Stanford Univ. Pubs. Geol. Sci., v. 11, p. 22-41.

Brown, R. D., Jr., and Wolfe, E. W., 1970, Map showing recently active breaks along the San Andreas fault between Pt. Delgada and Bolinas Bay, California: U.S. Geol. Survey, Basic Data Contr. 1, scale 1:48,000.

California Department of Water Resources, 1966, Final geologic report on the construction of the South Bay aqueduct terminal facilities: California Dept. Water Res., Project Geology Rept. C-12.

Castle, R. O., 1966, Preliminary study of the geology at two proposed sites for a nuclear-powered desalting plant near Sunset Beach and Pelican Point, Orange County, California: U.S. Geol. Survey report, prepared on behalf of the U.S. Atomic Energy Comm., January 1966, 73 p.

City of Hayward, Planning Commission Subcommittee on Land Use and Development Regulations, 1972, Hayward earthquake study: Hayward City Planning Commission, Calif., 50 p.

Diplock, L. R., and Nichols, D. R., 1972, Governmental responses to development hazards in California, in Microzonation Conference: Internat. Conf. on Microzona- 
tion for Safer Construction Research and Application, Seattle, Wash., Oct. 30-Nov. 3, 1972, Proc., v. II, p. 837-843.

Evernden, J. F., Hibbard, R. R., and Schneider, J. F., 1972, Interpretation of seismic intensity data, in Microzonation Conference: Internat. Conf. on Microzonation for Safer Construction Research and Application, Seattle, Wash., Oct. 30-Nov. 3, 1972, Proc., v. I, p. 363-378.

Grading Codes Advisory Board and Building Code Committee, 1973, Geology and earthquake hazards - Planners Guide to the Seismic Safety Element: Assoc. Eng. Geologists, Southern California Section, 44 p.

Hansen, W. R., Eckel, E. B., Schaem, W. E., Lyle, R. E., George, Warren, and Chance, Genie, 1966, The Alaska earthquake, March 27, 1964: Field investigations and reconstruction effort: U.S. Geol. Survey Prof. Paper 541, 111 p.

Hudson, D. E., 1972, Strong motion seismology, in Microzonation Conference: Internat. Conf. on Microzonation for Safer Construction Research and Application, Seattle, Wash., Oct. 30-Nov. 3, 1972, Proc., v. I, p. 29-60.

Kawasumi, Hirosi, ed., 1968, General report on the Niigata earthquake of 1964: Tokyo, Japan, Tokyo Electrical Engineering College Press, pl. 7.

Kiersch, G. A., 1964, Vaiont reservoir disaster: Civil Engineering, v. 34, no. 3, p. 32-39.

Longwell, C. R., Knopf, Adolph, and Flint, R. F., 1949, Physical geology: New York, John Wiley \& Sons, 602 p.

Mader, G. G., 1972, Land use planning, in Gates, G. O., ed., The San Fernando earthquake of February 9, 1971 and public policy: Spec. Subcommittee of the Joint Committee on Seismic Safety, California Legislature, p. 73-89.

Mader, G. G., Danehy, E. A., Cummings, J. C., and Dickinson, W. R., 1972, Land use restrictions along the San Andreas fault in Portola Valley, California, in Microzonation Conference: Internat. Conf. on Microzonation for Safer Construction Research and Application, Seattle, Wash., Oct. 30-Nov. 3, 1972, Proc., v. II, p. 845-857.

McCulloch, D. S., 1966, Slide-induced waves, seiching, and ground fracturing caused by the earthquake of March 27 1964, at Kenai Lake, Alaska: U.S. Geol. Survey Prof. Paper 543-A, p. A1-A41.

Miller, D. J., 1960, Giant waves in Lituya Bay, Alaska: U.S. Geol. Survey Prof. Paper 354-C, p. 51-86.

Newmark, N. M., Robinson, A. R., Ang, A. H.-S., Lopez, L. A., and Hall, W. J., 1972, Methods for determining site characteristics, in Microzonation Conference: Internat. Conf. on Microzonation for Safer Construction Research and Application, Seattle, Wash., Oct. 30-Nov. 3, Proc., v. I, p. 113-129.

Nichols, D. R., and Campbell, C. C., eds., 1971, Environmental planning and geology: U.S. Geol. Survey and U.S. Dept. Housing and Urban Development, 204 p.
Nichols, D. R., Lajoie, K. R., and Helley, E. J., 1972, Geologic parameters for ground response maps, in Microzonation Conference: Internat. Conf. on Microzonation for Safer Construction Research and Application, Seattle, Wash., Oct. 30-Nov. 3, 1972, Proc., v. II, p. 860-861.

Nilsen, T. H., 1971, Preliminary photointerpretation map of landslide and other surficial deposits of the Mount Diablo area, Contra Costa and Alameda counties, California: U.S. Geol. Survey Misc. Field Studies Map MF-310, scale $1: 62,500$.

Nilsen, T. H., and Brabb, E. E., 1972, Preliminary photointerpretation and damage maps of landslide and other surficial deposits in northeastern San Jose, Santa Clara County, California: U.S. Geol. Survey Misc. Field Studies Map MF-361.

Page, R. A., Boore, D. M., Joyner, W. B., and Coulter, H. W., 1972 , Ground motion values for use in the seismic design of the trans-Alaska pipeline system: U.S. Geol. Survey Circ. 672, 23 p.

Radbruch, D. H., 1967, Approximate location of fault traces and historic surface ruptures within the Hayward fault zone between San Pablo and Warm Springs, California: U.S. Geol. Survey Misc. Geol. Inv. Map I-522, scale 1:62,500.

Richter, C. F., 1958, Elementary seismology: San Francisco, W.H. Freeman, 768 p.

Seed, H. B., 1972, Dams and soils, in Gates, G. O., ed., The San Fernando earthquake of February 9, 1971 and public policy: Spec. Subcommittee of the Joint Committee on Seismic Safety, California Legislature, p. 13-33.

Seed, H. B., and Schnabel, P. B., 1972, Soil and geologic effects on site response during earthquakes, in Microzonation Conference: Internat. Conf. on Microzonation for Safer Construction Research and Application, Seattle, Wash., Oct. 30-Nov. 3, 1972, Proc., v. I, p. 61-85.

Seed, H. B., Whitman, R. V., Dezfulian, Houshang, Dobry, Ricardo, and Idriss, I. M., 1972, Soil conditions and building damage in 1967 Caracas earthquake: Am. Soc. Civil Engineers Proc., Jour. Soil Mechanics and Found. Div., v. 98 , no. 8 , p. $787-806$.

Town and Country Planning Branch, Ministry of Works, 1965, Town planning and earthquake faults: Ministry of Works, Bull. no. 7, p. 1-6, Wellington, New Zealand.

Wallace, R. E., 1968a, Notes on stream channels offset by the San Andreas fault, southern Coast Ranges, California, in Dickinson, W. R., and Grantz, Arthur, eds., Proceedings of conference on geologic problems of San Andreas fault system: Stanford Univ. Pubs. Geol. Sci., v. 11, p. 6-21. 1968b, Minimizing earthquake hazards: Am. Inst. of Architects Jour., v. 19, no. 1, p. 65-69.

Youd, T. L., 1971, Landsliding in the vicinity of the Van Norman Lakes, in The San Fernando, California, earthquake of February 9, 1971: U.S. Geol. Survey Prof. Paper 733, p. 105-109. 
